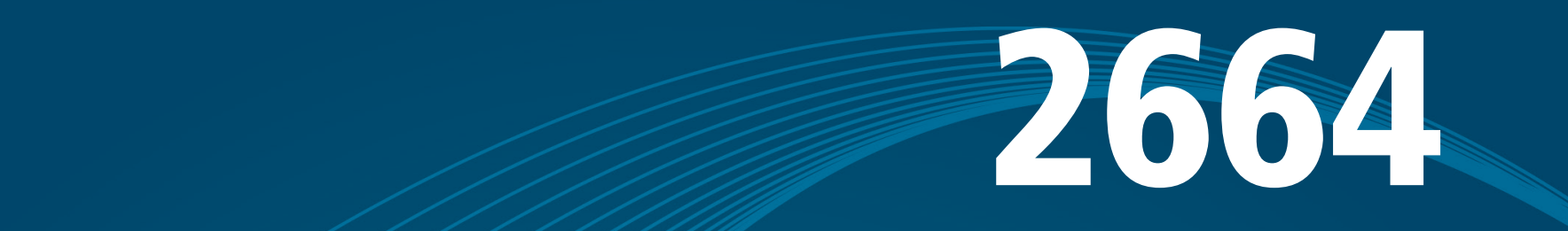

\title{
POLÍTICA REGIONAL NA UNIÃO EUROPEIA: TRANSFORMAÇÕES RECENTES E RECOMENDAÇÕES PARA O CASO BRASILEIRO
}

\author{
José Raimundo Oliveira Vergolino
}

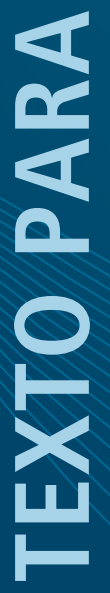





\section{TEXTO PARA DISCUSSÃO}

Brasília, junho de 2020

POLÍTICA REGIONAL NA UNIÃO EUROPEIA: TRANSFORMAÇÕES RECENTES E RECOMENDAÇÕES PARA O CASO BRASILEIRO

José Raimundo Oliveira Vergolino

1. Especialista em desenvolvimento regional. Professor aposentado da Universidade Federal de Penambuco (UFPE). 


\section{Governo Federal}

Ministério da Economia

Ministro Paulo Guedes

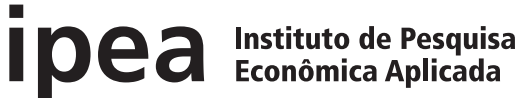

Fundação pública vinculada ao Ministério da Economia, o Ipea fornece suporte técnico e institucional às ações governamentais - possibilitando a formulação de inúmeras políticas públicas e programas de desenvolvimento brasileiros - e disponibiliza, para a sociedade, pesquisas e estudos realizados por seus técnicos.

Presidente

Carlos von Doellinger

Diretor de Desenvolvimento Institucional

Manoel Rodrigues Junior

Diretora de Estudos e Políticas do Estado, das Instituições e da Democracia

Flávia de Holanda Schmidt

Diretor de Estudos e Políticas Macroeconômicas José Ronaldo de Castro Souza Júnior

Diretor de Estudos e Políticas Regionais, Urbanas e Ambientais

Nilo Luiz Saccaro Júnior

Diretor de Estudos e Políticas Setoriais de Inovação e Infraestrutura

André Tortato Rauen

Diretora de Estudos e Políticas Sociais Lenita Maria Turchi

Diretor de Estudos e Relações Econômicas e Políticas Internacionais

Ivan Tiago Machado Oliveira

Assessor-chefe de Imprensa e Comunicação André Reis Diniz

Ouvidoria: http://www.ipea.gov.br/ouvidoria

URL: http://www.ipea.gov.br

\section{Texto para Discussão}

Publicação seriada que divulga resultados de estudos e pesquisas em desenvolvimento pelo Ipea com o objetivo de fomentar o debate e oferecer subsídios à formulação e avaliação de políticas públicas.

(C) Instituto de Pesquisa Econômica Aplicada - ipea 2021

Texto para discussão / Instituto de Pesquisa Econômica Aplicada.- Brasília : Rio de Janeiro : Ipea , 1990-

ISSN 1415-4765

1.Brasil. 2.Aspectos Econômicos. 3.Aspectos Sociais. I. Instituto de Pesquisa Econômica Aplicada.

CDD 330.908

As publicações do Ipea estão disponíveis para download gratuito nos formatos PDF (todas) e EPUB (livros e periódicos).

Acesse: http://www.ipea.gov.br/portal/publicacoes

As opiniões emitidas nesta publicação são de exclusiva e inteira responsabilidade dos autores, não exprimindo, necessariamente, o ponto de vista do Instituto de Pesquisa Econômica Aplicada ou do Ministério da Economia.

É permitida a reprodução deste texto e dos dados nele contidos, desde que citada a fonte. Reproduções para fins comerciais são proibidas. 


\section{SUMÁRIO}

SINOPSE

ABSTRACT

1 INTRODUÇÃO 7

2 A UNIÃO EUROPEIA: BREVES NOTAS HISTÓRICAS .8

3 A QUESTÃO REGIONAL: O NÓ GÓRDIO 11

4 A POLÍTICA DE COESÃO: FUNDAMENTOS 14

5 POLÍTICA DE COESÃO: OS INSTRUMENTOS

6 AVALIANDO O CASO EUROPEU: INTERPRETAÇÕES E ACHADOS 21

7 A ABORDAGEM DA BASE DO TERRITÓRIO: A CONTRIBUIÇÃO DE BARCA (2009)....33

8 LIÇÕES A INCORPORAR NO CASO DO BRASIL 36

9 POLÍTICA DE COESÃO VERSUS PNDR: UM CONTRAPONTO .45

10 CONCLUSÕES E RECOMENDAÇÕES .72

REFERENCIAS .74 



\section{SINOPSE}

O trabalho tem como objetivo principal comparar a política regional da Uniáo Europeia (UE) com a política regional no Brasil. Nesse contexto, intenta-se escrutinar as transformaçôes que ocorreram nas últimas duas décadas nas políticas e nos instrumentos promotores do desenvolvimento econômico e social dos países que formam a UE. A experiência da política regional desse bloco pode, em muitos aspectos, emular os pesquisadores brasileiros e os governos nacional e subnacionais a desenhar e implementar boas políticas públicas para enfrentar as desigualdades regionais. A Política Nacional de Desenvolvimento Regional (PNDR), de responsabilidade do governo federal, apresentou avanços substanciais no período 2007-2020. Contudo, o Fundo Nacional de Desenvolvimento Regional (FNDR), principal vetor de transformaçôes estruturais e que forneceria suporte financeiro à criação de políticas e programas no nível do território nacional, não foi criado. A ausência de tal instrumento representa grande restrição a maior efetividade da PNDR ao processo de minimização das desigualdades regionais no Brasil.

Palavras-chave: desenvolvimento regional; política regional; desenvolvimento econômico; União Europeia.

\section{ABSTRACT}

The main objective of this paper is to compare the European Union's (EU) Regional Policy with the Regional Policy in Brazil. In this context, the transformations that have occurred in the last two decades in the policies and instruments that promote the economic and social development of the countries that form the EU are discussed. The experience of EU Regional Policy can, in many ways, emulate Brazilian researchers and national and sub-national governments, to design and implement good public policies to address regional inequalities. The National Policy for Regional Development (PNDR), under the responsibility of the federal government, showed substantial advances in the period 2007-2020. However, the National Fund for Regional Development (FNDR), the main vector of structural changes and which would provide financial support for the creation of Policies and Programs at the national level, was not created. The absence of such an instrument represents a major constraint on the greater effectiveness of the PNDR to the process of minimizing regional inequalities in Brazil.

Keywords: regional development; regional policy; economic development; European Union. 



\section{INTRODUÇÃO}

Este estudo está voltado para a análise da política regional da União Europeia (UE) e para as contribuições que essa análise pode oferecer às discussóes sobre essa forma de política no Brasil. Nesse contexto, intenta-se escrutinar as transformaçôes que ocorreram nas últimas duas décadas nas políticas e nos instrumentos promotores do desenvolvimento econômico e social dos países que formam a UE. Pretende-se mostrar que o sucesso da União no período pós-guerra é resultado da cooperação. No topo da agenda dos líderes/fundadores desse bloco, estava a questão das desigualdades inter e intra Estados-membros. A solução exigia a construção de instrumentos de política de desenvolvimento (crescimento econômico com igualdade social) que envolvessem todo o território da UE. A Política de Coesão (PC), criada por meio de tratado específico, com a chancela de todos os Estados-membros, foi a solução. A problemática das desigualdades regionais (países, regióes e cidades avançadas e atrasadas) encontra-se no cerne do desenvolvimento econômico do bloco. Para os líderes/fundadores, esse desenvolvimento deveria ser harmonioso, ao buscar-se o crescimento econômico com ampla melhoria do bem-estar social de todos os cidadãos europeus. As evidências disponíveis mostram que o processo foi exitoso no contexto europeu, embora as desigualdades persistam por conta do ponto de partida entre os Estados-membros ser desigual.

A experiência da política regional da UE pode, em muitos aspectos, emular os pesquisadores brasileiros e os governos nacionais e subnacionais a desenhar e implementar boas políticas públicas, com o objetivo de enfrentar as desigualdades regionais.

O trabalho compreende um total de dez seçóes, incluindo-se esta introdução. A primeira faz um breve resgate histórico do processo de criação da União Europeia. $\mathrm{Na}$ sequência, na segunda seção, discute-se a questão regional na União. Na terceira seção, dedica-se atenção especial à Política de Coesão, em que se apresentam os principais objetivos da política de desenvolvimento do bloco. Na quarta seção, apresentam-se os fundamentos da PC. Na quinta, revelam-se os instrumentos de tal política. Na sexta, realiza-se um uma avaliação do caso europeu. Na sétima seção, abre-se uma janela para analisar o relatório An agenda for a reformed cohesion policy de Fabrizio Barca (2009), documento que lança as bases da nova política de desenvolvimento regional da União Europeia. Na oitava seção, analisam-se as liçóes que podem ser incorporadas ao caso do Brasil. Na nona, procura-se fazer um contraponto entre a Política de Coesão da UE com 
nossa Política Nacional de Desenvolvimento Regional (PNDR), em sua nova versão. Finalmente, destacam-se as conclusôes e as recomendações.

\section{A UNIÃO EUROPEIA: BREVES NOTAS HISTÓRICAS}

No atual contexto internacional, a UE é o maior bloco econômico do mundo, sendo formado por 28 países-membros, e compreende uma populaçáo de mais de 500 milhôes de pessoas, em que é livre a circulação de bens, pessoas e mercadorias, sob a égide de um mesmo sistema econômico (capitalismo) e operando com moeda única denominada euro.

A questão fundamental é: como os cidadãos europeus alcançaram essa façanha civilizatória, inédita para os padrôes da civilização ocidental?

A literatura que se debruça sobre essa questão é vasta, e as evidências disponíveis indicam que o fator econômico, como muitos podem imaginar e acreditar, náo foi a única razão que norteou a criação da Uniāo. A geopolítica da época pós-guerra teve papel fundamental no processo de unificação (Baldissera, 2018). ${ }^{1}$

Em primeiro lugar, a existência de dois modelos econômicos claramente antagônicos: o projeto da Uniáo Soviética, embasado em um modelo de economia planificada, conflitava com o modelo de economia de mercado adotado pelos futuros membros da futura União. A invasão da Tchecoslováquia em 1948 representou um sinal extremamente preocupante, aos líderes europeus e não europeus, do projeto de expansão da União Soviética. O sentido de pertencimento dos cidadãos europeus e seus líderes, favoráveis à economia de mercado até mesmo diante das adversidades materiais, era extremamente elevado. Tal sentimento aflorou com a criação do Plano de Reconstrução da Europa (Plano Marshall de 1947), desenhado e apoiado pelo governo americano, que injetou US\$ 12 bilhōes em auxílio para a reconstrução dos países da Europa Ocidental, afetados pela guerra. Esse plano atuou como um fator de contenção dos planos expansionistas do governo soviético. A Guerra Fria havia se instalado. Sem embargo de sua contribuição, o Plano Marshall sinalizou aos líderes europeus da época o desenho de um projeto de hegemonia gestado na Casa Branca.

1. Disponivel em: <https://bit.ly/3uSDJat>.

8 
Em face desse conjunto de acontecimentos, os líderes europeus, ciosos de seu sentido de pertencimento, criam, em 1948, o Movimento Europeu Unido. Segundo Baldissera,

de 7 a 11 de maio de 1948, oitocentos delegados europeus e observadores canadenses e estadunidenses reuniram-se na Haia, nos Países Baixos, para o Congresso da Europa. Organizado pelo Comitê Internacional dos Movimentos para a Unidade Europeia e presidido por Winston Churchill, o Congresso aproximou representantes de um amplo espectro político, promovendo-lhes a oportunidade para discutir ideias acerca do desenvolvimento da União Europeia. Importantes figuras políticas, como Albert Coppé, Altiero Spinelli, François Mitterand, Harold Macmillan, Konrad Adenauer, Paul-Henri Spaak e Winston Churchill, assumiram um papel ativo no Congresso, e uma chamada foi divulgada para a Uniáo da Europa, que se daria nos âmbitos monetário, econômico e político. Esta conferência teria uma influência significativa na formação do Movimento Europeu, que seria criado pouco tempo depois (Baldissera, 2018, p. 8).

A partir das discussóes desenvolvidas nessa conferência, foi dada a partida para a construção e a aprovaçáo de uma sequência de acordos de cooperação que culminaria com a criação da UE.

O primeiro foi o Tratado de Paris (1951-1952), que instituiu a Comunidade Europeia do Carvão e do Aço (Ceca), subscrito pela Alemanha, França, Itália e pelo Benelux (Bélgica, Holanda e Luxemburgo). A reindustrialização da Europa constituía um dos vetores para o crescimento e o desenvolvimento econômico regional. Nesse sentido, a oferta crescente de energia representava elemento vital para o crescimento das atividades industriais e, também, para a geração de energia elétrica voltada ao suprimento das aglomeraçóes urbanas, em franca recuperação. Havia uma assimetria entre os países na disponibilidade de carvão e minério de ferro, matérias-primas chaves para alavancar o processo. As minas de carváo mineral e minério de ferro estavam fortemente concentradas na região da Alsácia-Lorena (França) e do Sarre (Alemanha). O Tratado de Paris permitiu o compartilhamento dessas duas fontes de matéria-prima entre os países membros, livres de taxas de importação, e estimulou assim um processo de desenvolvimento mais equilibrado.

A primeira experiência de cooperação mostrou-se exitosa e ensejou novos avanços, agora voltados para a ampliação do mercado consumidor e a aceleração do processo de industrialização. Os países subescritores do Acordo de Paris reuniram-se em Roma, em março de 1957, e subscreveram dois acordos (Tratados de Roma), com o estabelecimento 
da Comunidade Econômica Europeia (CEE) e da Comunidade Europeia para a Energia Atômica (CEEA).

Trata-se de um novo patamar de cooperação entre um grupo de países, com propostas inovadoras nos segmentos do comércio inter-regional e internacional, meio ambiente, relaçóes de trabalho, segurança e crescimento econômico. Os países-membros da CEE procuraram avançar no desenho do Mercado Comum Europeu (MCE), ao estimularem a incorporação de novos países ao grupo. Após um longo interregno de funcionamento da CEE, foi criado o Ato Único Europeu, que promoveu a incorporaçáo, em 1986, da Espanha, de Portugal, do Reino Unido, da Dinamarca, da Grécia e da Itália ao grupo do tratado de Roma. O Ato Único Europeu começa a operar em julho de 1987. Anterior à criação do ato, as lideranças preocupadas com as desigualdades regionais avançaram criando a Diretoria-Geral de Política Regional, em 1968, responsável por desenhar e implementar uma política territorial para a região. Os esforços para diminuir as desigualdades regionais exigia um aporte significativo de recursos para investimento. Para equacionar esse problema, foi iniciado em 1972 o processo legislativo de criação do Fundo Europeu de Desenvolvimento Regional (Feder), que, em 1975, entra em processo de plena operacionalização. O sentido da criação do fundo era dar sustentabilidade à política regional. Em 1981, a Grécia adere ao MCE. Em 1986, é a vez de Portugal e Espanha. A entrada desses dois últimos ampliou consideravelmente o grau de disparidades regionais entre os Estados-membros da comunidade. ${ }^{2}$ Em 1988, é aprovado o primeiro regulamento que deu origem à PC. A proposta de criação da futura União Europeia estava em franca gestação.

Na sequência, foi assinado o Tratado de Maastricht, que criou a UE. O tratado foi subscrito em fevereiro de 1992 e tornou-se operacional em novembro de 1993. Com o tratado, ficou estabelecida a livre circulação de pessoas, mercadorias, bens e serviços entre os países-membros. Foi aprovada também a união monetária, com a criação de

2. Barca afirma "The reform was pushed by concerns about the different effects on regions of technological change and the Community's policy of market integration and liberalisation. As stated in the Padoa-Schioppa Report38, 'there are serious risks of aggravated regional imbalance in the course of market liberalisation (...) and adequate accompanying measures are required to speed adjustment in structurally weak regions and countries (...) reforms and development of Community structural funds are needed for this purpose'. It was also prompted by the accession of Spain and Portugal in 1986, which substantially widened regional disparities across the Community" (Barca, 2009, p. 15, grifo nosso). 
moeda única denominada euro. A partir de 2002, a moeda entrou em circulação entre os países-membros, exceto Dinamarca e Reino Unido, que preferiram manter suas moedas.

O esforço das lideranças políticas da época em criar uma uniáo monetária e econômica partia do pressuposto de que tal estratégia apresentaria fortes efeitos sobre as desigualdades de renda e produto entre os Estados-membros, como de fato aconteceu.

\section{A QUESTÃO REGIONAL: 0 NÓ GÓRDIO}

A questáo regional, no contexto europeu, está relacionada à existência de elevadas desigualdades nos níveis de renda, produto per capita e qualidade de vida inter e intrarregional, e de que forma tal conjuntura poderia prejudicar os avanços no processo de criação de um bloco econômico perfeitamente integrado.

A síntese histórica elaborada por Barca (2009) fornece uma boa compreensão do problema, e será utilizada ao longo desse ensaio.

O Tratado de Roma, de 1957, que promoveu a criação da CEE, destaca, em seu preâmbulo, a necessidade de alcançar o desenvolvimento de forma harmoniosa dos Estados-membros. Isso implicava reduzir as diferenças econômicas entre as regiôes e, também, superar o atraso das regiōes menos desenvolvidas. Todavia, os signatários do tratado ainda não estavam convictos da necessidade de criar, na ocasiáo, uma política regional explícita nos moldes do atual modelo em operação. Segundo Barca (2009), ${ }^{3}$ a escolha foi intencional por duas razōes. Em primeiro lugar, porque as lideranças acreditavam que as propostas contidas no Tratado de Roma seriam capazes de alavancar as trocas comerciais entre os Estados-membros. O comércio inter-regional seria capaz de

3. "The founding fathers of the European Economic Community (EEC, later the European Union) had mixed feelings about the creation of a Community regional policy. In the preamble to the Treaty of Rome, they declared themselves 'anxious to strengthen the unity of their economies and to ensure their harmonious development by reducing the differences existing among the various regions and the backwardness of the less-favoured regions'. However, while their spatial awareness is clear from several Treaty statements, the founders did not provide a firm basis for establishing an autonomous Community regional policy (...) The choice was intentional for two main reasons. First, there was a general, and arguably overoptimistic, feeling that integration in itself would contribute to reducing regional disparities through the promotion of inter-regional trade27. Secondly, the experience with domestic regional policy in a number of the countries -France, Italy and Germany was relatively recent and it was not felt necessary to duplicate or interfere with this" (op. cit., p. 13). 
estimular o crescimento econômico e, assim, provocar aumento de produto e renda. Dessa forma, beneficiaria os países e as regióes mais atrasadas. A segunda razão estava relacionada ao fato de que alguns países - como Alemanha, França e Itália - haviam implementado experiências de política de cunho regional, ainda que recentes, e que era necessário aguardar os efeitos dessas açôes no território. O caso mais emblemático é a política italiana para o Mezzogiorno. ${ }^{4}$ Em 1965, foi assinado o Tratado de Bruxelas, também conhecido como Tratado de Fusão. Após um longo intervalo de aproximadamente duas décadas, foi assinado o Ato Único Europeu (1986).

Nesse longo interregno, ocorreram grandes avanços no processo de construção de modelo de política regional que envolvesse todos os Estados-membros signatários dos tratados. Um acontecimento da mais alta relevância foi a criação do Feder, cujo processo legislativo foi iniciado em 1973 e operacionalizado em 1975. Sem embargo de outras consideraçóes, dois objetivos estavam claramente explicitados no regulamento do fundo: i) a questão da eficiência; e ii) a problemática da equidade.

A preocupação com a eficiência estava relacionada aos níveis de competitividade do sistema econômico dos países-membros, que eram desiguais. Dever-se-ia perseguir a plena utilização dos fatores produtivos e taxas elevadas de crescimento econômico, a fim de gestar um processo de convergência. Em relação ao objetivo de igualdade, havia o pressuposto de que ocorreria um processo de desenvolvimento na esteira do crescimento econômico, em que o resultado final seria a melhoria dos níveis de bem-estar dos residentes dos países-membros.

Segundo Barca (2009), grandes avanços foram alcançados nessa agenda de crescimento versus distribuição. Destaque-se a criação do Programa do Mediterrâneo Integrado (1985), inserido no Ato Único Europeu (1986), no qual se destacava a proposta de coesão, com o objetivo de promover o desenvolvimento harmonioso de todos os Estados-membros. Por meio da criação da União Europeia, pelo Tratado de Maastricht (1991-1993), foi criado o Fundo de Coesão (FC), cujo objetivo principal era fornecer recursos para os países mais atrasados em termos econômicos e sociais. Mudanças importantes foram

4. "Italy has a long tradition in regional policy, at least since the fifties. Long before the start of the European cohesion policy, the Mezzogiorno regions were addressed through a major cohesion policy (the so-called "Intervento straordinario") pursued by a special public institution (the "Cassa per il Mezzogiorno") whose activities lasted from 1951 to 1992. In the subsequent years a number of different, less generous, nationally-funded programs took place" (Barone, David e Blasio, 2016). 
introduzidas na questấo relacionada à alocação dos recursos do fundo. Destaque-se, nesse sentido, a liberdade que os Estados-membros obtiveram em formular os programas de desenvolvimento que eram encaminhados à Comissão Central e, assim, aprovados. Em meados da década de 1990 (1994), foi apresentada aos Estados-membros a Estratégia Europeia de Emprego, que se tornou ponto de referência no desenho de programas na esfera social. O FC gravitava em torno de alguns princípios. Foi criado o princípio da parceria, em que as autoridades regionais e locais deveriam estar plenamente envolvidas na formulação e na implementação dos programas de sua regiâa. Esse engajamento da sociedade, da base para o topo, constituiu um dos grandes avanços da PC da UE. É desse período o princípio da adicionalidade, que estabelecia que os gastos nas comunidades, apoiados pelo fundo, não deveriam simplesmente substituir as despesas oriundas do orçamento do Estado-membro, e sim complementá-las.

O sucesso de um projeto de união de países, com diferentes culturas e valores, formação política desigual e extremamente heterogêneos em se tratando do estoque de capital social básico dependia, em larga medida, de um cardápio de projetos cujo objetivo central era o desenvolvimento econômico.

O desenho da PC representou a melhor estratégia para o sucesso do projeto de criação da União Europeia. Mas não foi o fator econômico o único determinante para a unificação. Acontecimentos de natureza política também contribuíram para acelerar a criação da UE. Líderes de campos ideológicos táo diferentes, como Miterrand (França), Kohl (Alemanha), Thatcher (Reino Unido) e Felipe Gonzalez (Espanha), mas dotados de grande sensibilidade política e social, foram capazes de convergir e contribuir decisivamente para a construção da UE.

Cite-se, como primeiro destaque, o fim dos regimes ditatoriais que ocorreram em dois países da Península Ibérica: o colapso das ditaduras de Salazar em Portugal e do Generalíssimo Franco na Espanha (1974-1975). Em segundo, o fim do modelo de economia planificada, liderado pela União Soviética, que provocou a desintegração política de inúmeros Estados da órbita soviética. $\mathrm{O}$ exemplo mais icônico é o caso da Alemanha Oriental que se integra à Ocidental, formando uma Alemanha única, em 1989. Todos esses acontecimentos políticos afetaram de algum modo, e para melhor, o comportamento psicossocial dos residentes nos países membros. Até mesmo vivendo em condiçóes materiais adversas, a comunidade desses países resgatou um valor precioso 
que foi a liberdade de ir e vir sem as amarras da burocracia autoritária, de empreender sem os constrangimentos institucionais e, mais importante, de sonhar com um futuro mais promissor, inclusive diante de cenário econômico e social adverso.

De uma forma sintética, pode-se afirmar que a questão regional, como definida em parágrafo anterior, sempre esteve no cerne da construção do projeto da União Europeia. As elevadas desigualdades em ritmo de crescimento e nos níveis de bem-estar entre os Estados-membros, além das desigualdades nas fronteiras de cada Estado, representaram, sem sombra de dúvida, um verdadeiro entrave de natureza política para o sucesso do empreendimento da UE.

\section{A POLÍTICA DE COESÃO: FUNDAMENTOS}

Como destacado em parágrafo precedente, em 1988, foi criado o $1^{\circ}$ Regulamento da Política de Coesão. Nesse documento, foram estabelecidos os princípios básicos da política:

1) Concentração em um número limitado de objetivos, centrados nas regiôes menos desenvolvidas;

2) Programação plurianual baseada na análise, planejamento estratégico e avaliação;

3) Adicionalidade, assegurando assim que os Estados-membros não substituíssem o financiamento nacional por financiamento da UE;

4) Parceria na concepção e execução de programas que envolvessem intervenientes nacionais, regionais e da UE, incluindo os parceiros sociais e organizaçóes não governamentais, e assegurassem a apropriação e a transparência das intervençóes.

Embasado no documento que trata da regulação da PC, foram estabelecidos entre as partes cinco objetivos que deveriam ser perseguidos nos termos dos projetos encaminhados à Comissão Europeia. Eram estes:

1) Objetivo 1: promover o desenvolvimento e o ajustamento estrutural das regióes menos desenvolvidas;

2) Objetivo 2: reconverter as regióes gravemente afetadas pelo declínio industrial;

3) Objetivo 3: lutar contra o desemprego de longa duração;

4) Objetivo 4: facilitar a inserção profissional dos jovens; 
5) Objetivo 5:

a) acelerar a adaptação das estruturas agrícolas; e

b) promover o desenvolvimento das zonas rurais (UE, 2008, p. 10).

Como destacado pela própria denominação, a PC é uma política de uma instituição supranacional, e não de Estado, ${ }^{5}$ cujo cerne é a cooperação entre os Estados-membros para alcançar um desenvolvimento mais harmonioso do conjunto dos elementos. Baleiras (2020), em texto provocante, destaca três singularidades dessa política. Em primeiro lugar:

a coesão econômica, social e territorial é um valor fundamental e um vetor político da UE. Coesão é a expressão mais forte do princípio da UE, a solidariedade na construção europeia e a sua prossecução é um objetiv/o para as várias políticas europeias, e não apenas para a Política de Coesão (Baleiras, 2020).

Em segundo, “a Política de Coesão é a política de desenvolvimento econômico para os territórios da UE. Isto significa duas coisas: é uma política estrutural e é uma política baseada nos lugares" (Baleiras, 2020). Finalmente, o autor enfatiza o componente político desta, ao afirmar que "a Política de Coesão traz um valor acrescentado extremamente significativo para a União e cada Estado-membro. No plano mais político, é a melhor expressão do valor constitucional da solidariedade" (op. cit.).

Sem embargo de outras consideraçóes relevantes sobre a PC, torna-se importante destacar os principais instrumentos de operacionalização de tal política.

\section{POLÍTICA DE COESÃO: OS INSTRUMENTOS}

A fim de garantir efetividade à $\mathrm{PC}$ e, por rebatimento, a implementação de uma política que observasse as diferenças regionais de desenvolvimento entre os Estados-membros, foi iniciado em 1973 o processo legislativo para a criação do Feder. Barca (2009, p. 14-15) destaca a importância dos fundos para o desenvolvimento das regióes mais atrasadas. Trata-se de complemento ao orçamento de investimentos dos Estados-membros

5. "The hybrid government of the EU is the result of a relatively recent choice made by very dissimilar communities which have been in conflict for centuries. It does not have federal powers and very different views coexist on what the limits of its powers should be. It largely relies on lower levels of government to allocate resources for development, establish priorities and manage spending" (Barca, 2009, p. 12). 
receptores. O princípio da adicionalidade estabelecia que os recursos oriundos da UE não poderiam substituir as despesas de investimento derivadas de recursos orçamentário do Estado-membro.

\subsection{Os fundos estruturais}

Uma parte significativa dos recursos orçamentários da UE é alocada nos cinco fundos europeus estruturais e de investimento (FEEIs). Os recursos desses fundos são administrados em conjunto pela Comissão Europeia e pelos Estados-membros. Esses fundos têm como principal objetivo carrear recursos de investimento para a promoção do desenvolvimento nos contextos econômico, social e do meio ambiente.

\subsubsection{O Fundo Europeu de Desenvolvimento Regional}

O Fundo Europeu de Desenvolvimento Regional tem como objetivo básico promover o desenvolvimento equilibrado entre as diferentes regióes dos Estados-membros (UE, 2006a). O regulamento do Parlamento Europeu estabelece no capítulo 1ํㅡㄹ art. 2o das disposiçôes gerais, os objetivos do Feder, conforme a seguir descrito.

Nos termos do artigo 160 do Tratado e do Regulamento (CE) no 1.083/2006, o Feder participa no financiamento da intervenção destinada ao reforço da coesão económica e social, corrigindo os principais desequilíbrios regionais através do apoio ao desenvolvimento e ao ajustamento estrutural das economias regionais, incluindo a reconversão das regiôes industriais em declínio e das regiôes menos desenvolvidas, e do apoio à cooperaçáo transfronteiriça, transnacional e inter-regional.

Dessa forma, o Feder dá cumprimento às prioridades da Comunidade e, em especial, à necessidade de reforçar a competitividade e a inovação, de criar e manter empregos sustentáveis e de assegurar o desenvolvimento sustentável (UE, 2006a).

\subsubsection{O Fundo Social Europeu (FSE)}

O FSE (UE, 2006b) é outro fundo de grande importância no processo de construção da UE. Trata-se da preocupação com a melhoria do nível de bem-estar dos cidadáos dos Estados-membros, por intermédio de investimentos em educação em todos os níveis, bem como no treinamento e na requalificação da força de trabalho.

Esse fundo aporta recursos para projetos relacionados com a geração de emprego nos Estados-membros e a formação de capital humano, o que inclui tanto trabalhadores 
formais quanto indivíduos demandando emprego. $\mathrm{O}$ regulamento no seu art. 2o trata dos objetivos do fundo e destaca os seguintes pontos:

O FSE contribui para as prioridades da Comunidade no que respeita ao reforço da coesão económica e social, melhorando o emprego e as oportunidades de emprego, promovendo um elevado nivel de emprego e mais e melhores empregos. Atua através do apoio às politicas dos Estados-membros destinadas a atingir o pleno emprego e a qualidade e produtividade no trabalho, a promover a inclusão social, nomeadamente o acesso das pessoas desfavorecidas ao emprego, e a reduzir as disparidades de emprego a nivel nacional, regional e local.

Em especial, o FSE apoia ações compatíveis com as medidas tomadas pelos Estados-membros com base nas orientaçóes no âmbito da Estratégia Europeia para o Emprego, incluídas nas Orientaçôes Integradas para o Crescimento e o Emprego, e nas recomendações de acompanhamento (UE, 2006b, grifo nosso).

\subsubsection{Fundo de Coesão}

Trata-se de fundo criado pela UE com vistas à infraestrutura (UE, 2006b). Quem quer que viaje pelos países-membros da UE, na condição de turista ou agente de negócios, se depara com a qualidade da infraestrutura de transportes, quer no nível das estruturas aeroportuárias, quer na condição das estradas principais e vicinais, quer nos espaços urbanos metropolitanos. Destaque especial para a qualidade da malha ferroviária, que conecta as principais cidades-capitais dos diferentes Estados-membros. Por último, há a qualidade do transporte urbano, como linhas de ônibus e trens urbanos, veículos leves sobre trilhos (VLTs), que conectam os principais espaços das principais cidades europeias. Além desses aspectos, há de destacar-se a excelente infraestrutura dos portos marítimos, representando uma das pontas do modal de transporte, que constitui um elemento fundamental no processo de crescimento econômico. As trocas internacionais, por meio das atividades de exportação e importaçáo de bens finais, produtos intermediários e insumos, utilizam intensamente esse modal de transporte.

Esse panorama exitoso das condições do modal de transporte dos Estados-membros da UE pode ser creditado, em parte, aos recursos proporcionados pelo FC. Trata-se de uma categoria de fundo que tem como objetivo básico contribuir para o incremento da coesão econômica e social da Uniáo Europeia, na perspectiva do desenvolvimento sustentável. As formas de transporte estão inseridas nesse contexto. Há de acrescentar-se a forte preocupação das comunidades dos Estados-membros com a questáo do meio 
ambiente; disso decorre que a política de energia renovável e limpa está presente como um importante objetivo do fundo.

De forma objetiva, o regulamento no seu art. $1^{\circ}$, que trata da criação e objetivos do FC estabelece:

1) O fundo intervém de forma equilibrada e adequada em açóes nos domínios seguintes, tendo em conta as necessidades específicas de investimento e infraestruturas de cada Estado-membro beneficiário: a) Redes transeuropeias de transportes, nomeadamente projetos prioritários de interesse europeu tal como definidos na Decisão n ${ }^{\circ}$ 1.692/96/CE; b) Questōes de ambiente que se inscrevam no âmbito das prioridades atribuídas à política comunitária de proteçẫo do ambiente ao abrigo da política e programa de ação em matéria de ambiente. Neste contexto, o fundo pode também intervir em domínios relativos ao desenvolvimento sustentável que apresentem benefícios ambientais claros, como a eficiência energética e as energias renováveis e, no domínio dos transportes que não façam parte das redes transeuropeias, os transportes ferroviários, fluviais e marítimos, os sistemas de transporte intermodais e sua interoperabilidade, a gestâo do tráfego rodoviário, marítimo e aéreo, o transporte urbano limpo e os transportes públicos (UE, 2006b).

\subsubsection{Fundo Europeu Agrícola de Desenvolvimento Rural (Feader)}

Trata-se de fundo criado pela União Europeia, com vistas ao desenvolvimento rural do bloco (UE, 2006b). O setor rural dos Estados-membros, embora apresente baixa taxa de geração de emprego e reduzida participação no produto interno bruto (PIB) da UE, destaca-se pelo seu valor intrínseco, difícil de mensurar, que está relacionado aos hábitos de origem cultural dos habitantes da região. Os fundadores da UE possuíam não apenas ampla compreensão dessa questão, como também grande sensibilidade para com os habitantes que derivavam renda da atividade laboral agrária. Em razão da base técnica de produção ser bastante heterogênea, com fortes rebatimentos sobre a distribuição de renda dos habitantes do setor, havia a necessidade de desenhar uma estratégia de desenvolvimento inclusiva e modernizante, que promovesse o desenvolvimento equilibrado do setor. O Feader foi criado com esse propósito. Trata-se de evolução do Fundo Europeu de Orientação e Garantia Agrícola (Feoga), criado em 1962. As prioridades para o setor estão assentadas nos seguintes itens:

- fomentar a transferência de conhecimentos e a inovação nos setores agrícola e florestal e nas zonas rurais; 
- reforçar a competitividade de todos os tipos de agricultura e reforçar a viabilidade das exploraçôes agrícolas;

- promover a organização de cadeias alimentares;

- promover a utilização eficiente de recursos e apoiar a transição para uma economia hipocarbônica e resiliente às alteraçôes climáticas nos setores agrícola, alimentar e florestal; e

- promover a inclusão social, a redução da pobreza e o desenvolvimento econômico das zonas rurais, em particular no que toca à criaçáo de pequenas empresas, assim como a criação de postos de trabalho (UE, 2006b).

\subsubsection{Fundo Europeu dos Assuntos Marítimos e das Pescas (Feamp)}

Trata-se de fundo criado pela Uniáo Europeia relativo às atividades marítimas e à pesca (UE, 2006b). A visão totalizante dos líderes fundadores da $\mathrm{UE}^{6}$ permitiu observar, com especial atenção, o papel das comunidades costeiras para o desenvolvimento econômico da União. Estados-membros que fazem limites com águas oceânicas e também mediterrânicas possuem uma longa tradição na atividade pesqueira. Trata-se de setor de grande importância tanto na oferta de proteína alimentar aos centros urbanos, quanto na geração de emprego e renda. Os principais objetivos do fundo são:

- promover uma pesca e uma aquicultura competitivas, ambientalmente sustentáveis, economicamente viáveis e socialmente responsáveis;

- fomentar a execução da PCP; e

- promover um desenvolvimento territorial e equilibrado das zonas de pesca e de aquicultura; Fomentar o desenvolvimento e a execução da PMI da Uniáo, em complementaridade com a Política de Coesão e com a PCP (UE, 2006b).

6. Commissioner for Environment, Maritime Affairs and Fisheries, Karmenu Vella, said: "Healthy, well-managed oceans are a pre-condition for long-term investments and job creation in fisheries and the broader blue economy. As a global ocean actor and the world's fifth largest producer of seafood, the European Union has a strong responsibility to protect, conserve and sustainably use the oceans and their resources. The Fund will allow Member States and the Commission to live up to that responsibility and invest into sustainable fisheries, food security, a thriving maritime economy, and healthy and productive seas and oceans." (EC, 2018). 


\subsubsection{Nomenclatura Comum das Unidades Territoriais Estatísticas (Nuts)}

O projeto da UE, com a envergadura imaginada pelos líderes fundadores exigia uma governança extremamente sofisticada. Nesse sentido, tornava-se necessário desenhar, criar e administrar uma base de informaçôes de caráter estatístico, a mais ampla possível, que compreendesse variáveis econômicas, sociais, ambientais, administrativas e de outras naturezas. Essa necessidade gravitava em torno da heterogeneidade estrutural dos Estados-membros, com população, área geográfica e economia bastante diferentes. Havia, portanto, a necessidade de criar uma base de informação que respondesse aos objetivos do Tratado de Maastricht da UE.

Atentando para esses aspectos, o Serviço de Estatística Europeu (Eurostat) criou as Nuts, a fim de permitir a aplicaçáo de uma norma estatística comum em toda a União Europeia. Os níveis Nuts são zonas geográficas definidas para a construçâo de dados harmonizados na UE. Trata-se de sistema de regionalização extremamente importante no quadro dos fundos estruturais e, desde 1988, desempenha um papel importante na dotação das verbas destes. A nomenclatura atual subdivide os Estados-membros em três categorias, estabelecidas com base em limites demográficos específicos. A tabela 1 apresenta os limites demográficos das Nuts.

TABELA 1

Nuts: limites populacionais

\begin{tabular}{lcc}
\hline Nivel & Mínimo & Máximo \\
\hline Nuts 1 & 3 milhões & 7 milhões \\
Nuts 2 & 800.000 & 3 milhões \\
Nuts 3 & 150.000 & 800.000 \\
\hline
\end{tabular}

Fonte: Barca (2009, p. 61).

"Para que as estatísticas regionais sejam comparáveis, as zonas geográficas devem ser também comparáveis em termos de população. As características política, administrativa e institucional são consideradas relevantes." Caso não existam unidades administrativas que se enquadrem nos limites populacionais destacados na tabela 1, então é realizada uma agregação de unidades administrativas de menor tamanho, contíguas. As unidades assim agregadas denominam-se unidades não administrativas. Eventualmente, as unidades não administrativas devem traduzir uma lógica económica, social, histórica, cultural, geográfica ou ambiental. 
As estatísticas regionais das Nuts têm regulação específica, estabelecida pelo Regulamento (CE) no1.059/2003, que garante a estabilidade das estatísticas regionais ao longo do tempo. O Estado-membro pode encaminhar à Comissão Europeia mudanças na regionalização de seu país, respeitando-se a regulação existente.

\section{AVALIANDO 0 CASO EUROPEU: INTERPRETAÇÕES E ACHADOS}

Em seção anterior, foram elencados os principais objetivos da PC na UE. Na oportunidade, foram apresentados os fundos estruturais e de investimento, principais instrumentos de promoção do desenvolvimento econômico dos Estados-membros. Uma parte significativa dos recursos do orçamento global do bloco é canalizada para esses fundos e alocada entre as regióes dos Estados-membros. Sem embargo de outros aspectos relevantes, a questáo da avaliaçấo dos impactos dos investimentos (despesas) nos diferentes territórios, com recursos dos diferentes fundos, sempre representou preocupação de primeira ordem da Comissão Europeia. Assim pensando, a dita comissão criou estruturas funcionais específicas, no organograma da UE, para realizar tais avaliaçóes.

Em paralelo aos estudos desenvolvidos pelas equipes de investigadores da UE, avançaram, de forma exponencial, as investigaçóes de natureza acadêmica, geradas nos centros universitários, institutos de pesquisa e fundaçôes, direcionadas à análise do impacto da PC no processo de desenvolvimento econômico e social dos Estados-membros.

O objetivo desta seção é a apresentação de algumas contribuiçôes, de natureza acadêmica, relativas à avaliação dos impactos econômicos e sociais da PC no território da UE.

\subsection{A Questão da convergência}

Como já pontuado anteriormente, a Política de Coesão determina, como objetivo primeiro, "a promoção do desenvolvimento e o ajustamento estrutural das regióes menos desenvolvidas". Para alcançar tal objetivo, os fundos estruturais (Feder, FSE etc.) devem alocar recursos em programas que potencializem as taxas de crescimento do produto, da renda e do emprego dos Estados-membros. A partir do estabelecimento de um cardápio de açóes estruturantes definidas em comum acordo entre os Estados-membros e a Comissão Europeia da UE e apoiadas em diagnósticos macrorregionais robustos, os 
recursos são canalizados em maior proporção para os Estados-membros de maior atraso relativo e, por via de consequência, suas respectivas regióes. Acreditava-se, desde a criação da PC, que tal estratégia promoveria um processo de convergência do PIB per capita entre Estados e nas regióes dos Estados-membros. O pensamento dominante entre os executivos da comissáo apoiava-se nos pressupostos da teoria neoclássica do crescimento. Segundo esse paradigma, os fatores de produção capital físico e trabalho fluem no território, segundo suas taxas de retorno. Regióes atrasadas possuem baixa dotação de capital físico (altas taxas de retorno) e grande quantidade de força de trabalho (baixos níveis de salário). O inverso acontece com as regiōes avançadas. Supondo concorrência perfeita, livre mobilidade dos fatores e produtividade marginal do capital decrescente, pode-se inferir que o capital físico migra para as regióes mais atrasadas e o trabalho migra para as regióes avançadas. Haverá, portanto, no longo prazo, processo de convergência das taxas de crescimento do produto per capita.

Essa percepção da Comissão Europeia foi amplificada quando do ingresso da Espanha, de Portugal e da Grécia na UE. A entrada desses países na comunidade provocou uma ampliação no grau de desigualdade econômica e social no contexto do bloco. Com base nos pressupostos neoclássicos, acreditava-se que esses países seriam beneficiados com aumento de dotação do fator escasso (capital), e assim haveria um crescimento mais acentuado vis-à-vis as economias mais avançadas. $\mathrm{O}$ processo de convergência estaria, pois, instalado.

Recorrendo-se às contribuiçôes mais recentes, destaca-se o trabalho desenvolvido por Crescenzi e Giua (2020), que apresenta instigantes questóes acerca dos resultados gerados pela PC na UE.

Os autores realizam sua avaliação pelo esforço de responder a três questóes, por eles tidas como cruciais, e que têm recebido pouca atenção dos estudiosos: ${ }^{7}$

7. "These fundamental questions are still unanswered. Most of the existing studies that employ counterfactual techniques in order to identify the impacts of Cohesion Policy conclude that the policy has a positive effect on growth and employment. These same studies also suggest that positive effects are contingent upon several local and policy conditions such as funds absorptive capacity, local context and intensity of treatment. However, all this evidence is only valid for the EU as a whole, with no insights into the country-specific nature of the estimated impacts, their heterogeneity across countries and possible composition effects" (Crescenzi e Giua, 2020, p. 11). 
1) Quais - e em que extensão - regióes em diferentes Estados-membros se beneficiaram da Política de Coesão?

2) Os impactos regionais são persistentemente diversificados entre os países?

3) Ainda faz sentido que todos os Estados-membros transfiram recursos nacionais para um fundo de política regional da UE? (Crescenzi e Giua, 2020, p. 11, tradução nossa).

Eles tentam responder às duas primeiras. Utilizam técnicas da econometria espacial para estimar os coeficientes do modelo. $\mathrm{O}$ valor agregado bruto (VAB) por regiáo e o emprego no setor manufatureiro como proxy para o emprego regional representam as variáveis dependentes em dois grupos de regressóes. Os autores testam o modelo para a Europa e, também, para quatro países de forma independente. Foram escolhidas as regiōes enquadradas na Nuts-3 (regióes entre 150 mil a 800 mil habitantes) da Alemanha, da Itália, da Espanha e do Reino Unido. Os autores testam o modelo para dois períodos de tempo: 2000-2010 e 2010-2014. Concentram sua atenção no Objetivo 1 da PC para responder à questão 1 .

Em relação à primeira questão, as estimativas do modelo para a Europa apresentam-se robustas, e os resultados encontrados mostram que a PC tem exercido um positivo e significativo impacto, tanto no que diz respeito ao crescimento econômico regional quanto no que concerne ao emprego. A hipótese da convergência sustenta-se. Em sequência, os autores testam o mesmo modelo para os quatro países escolhidos. Arguem se o crescimento do produto e do emprego se distribuiu de maneira uniforme entre os países da amostra. Os resultados das estimativas identificam um cenário que difere daquele apresentado para a Europa, quando analisada de forma integrada.

Segundo os autores, a Alemanha foi o país que apresentou os melhores resultados, tanto em termos de crescimento do produto quanto em relação ao crescimento do emprego. Os benefícios da PC foram extremamente positivos para as regióes da Alemanha, para os dois períodos analisados. Os investimentos estruturadores impactaram positivamente o produto, o que gerou processo de convergência. $\mathrm{O}$ crescimento do produto promoveu, 
por sua vez, o do emprego. Os resultados mostram que os benefícios regionais em termos de crescimento econômico estão concentrados nas regióes da Alemanha. ${ }^{8}$

As estimativas do modelo para o caso do Reino Unido indicam que o impacto dos investimentos nas taxas de crescimento do produto foi extremamente baixo, não configurando um cenário de convergência do produto bruto. Todavia, a trajetória do emprego mostrou-se positiva para os dois períodos estudados (2000-2010 e 2010-2014).

Em relação à Itália, a PC gerou impactos positivos que se materializaram somente nos indicadores de emprego para o período 2000-2010. Todavia, os efeitos positivos no emprego não se sustentaram no período 2010-2014, devido aos efeitos da grande recessão de 2008. Os autores acreditam que os investimentos realizados em regióes que subsidiam o trabalho de baixa produtividade, como é o caso do Mezzogiorno, podem explicar a trajetória do produto e, também, do emprego.

A Espanha é um caso especial. As regiôes do país foram beneficiárias de quase 30\% das despesas da UE no período 2000-2006. Todavia, a PC não foi capaz de promover o crescimento substancial do produto e do emprego nas regiôes do país. A explicação dos pesquisadores está associada ao fato de que o governo espanhol priorizou os recursos recebidos em investimentos na infraestrutura de transportes e minimizou os investimentos em educação e treinamento de jovens, bem como outros gastos na área social. As estimativas do modelo econométrico indicam que as regiôes da Espanha apresentam melhor performance no crescimento econômico no período 2010-2014, exatamente após a época da crise de 2008, mas, em relação à criação de emprego, os resultados apresentados pelo modelo foram extremamente negativos.

8. "How are these positive economic impacts distributed across countries? In terms of regional growth, Germany is the big winner from Cohesion Policy. The results show that regional benefits in terms of economic growth are concentrated in German regions that drive the whole-EU positive impact" (Crescenzi e Giua, 2020, p. 16). 
Os autores aproveitam a oportunidade para criticar as propostas de Barca (2009). ${ }^{9}$ Esse autor sugere em seu relatório que as intervenções econômicas voltadas para o crescimento e a criação de emprego devem concentrar-se no território e, também, que seja evitada a pulverização de atividades. A escolha de um grupo restrito de atividades favorece a maior eficiência alocativa com maior crescimento. $\mathrm{O}$ autor enfatiza em seu relatório a necessidade de convergência entre os interesses da Comissão Europeia e dos Estados-membros. Os planos, os programas e as estratégias desses Estados devem estar plenamente compatíveis com a PC. O autor destaca em seu relatório que essa compatibilidade nem sempre é alcançada por razóes econômicas e políticas, intrínsecas à história de cada país. Nesse sentido, a crítica dos autores às propostas de Barca não é consistente.

Outra importante contribuição foi dada por Iammarino, Rodrigues-Pose e Storper (2019), em relação à investigação dos impactos da PC sobre o desenvolvimento econômico e social das regióes da UE. Os autores enfatizam o sentido das políticas, chamando atenção para os aspectos de que as políticas baseadas nas pessoas (people-based policies) e a abordagem baseada no território (place-based approach) podem ser substituídas por uma terceira via, que eles denominam de sensibilidade territorial (place sensitive); esta seria uma combinação das duas abordagens tradicionais, que juntaria fatores micro (indivíduos) com uma lógica meso (territorial).

Com o objetivo de mostrar a lógica de sua proposta, elaboraram uma classificação das regióes da UE em quatro grupos com base no PIB per capita: i) regióes de elevadíssimo PIB per capita - ER (150\% ou acima da média da UE); ii) regióes de alto PIB per capita (regiôes entre 120\% e 149\% acima da média da UE; iii) regióes de PIB per capita médio (75\% e 119\% acima da média da UE); e iv) regióes pobres (menos de 75\% do PIB per capita médio da UE). As regióes de elevadíssimo PIB per capita estão localizadas nas grandes regióes metropolitanas (RMs) e nas cidades (capitais de alguns países). Existe também uma rede de cidades de médio porte que se enquadram nesse grupo, especialmente as localizadas no vale do Rhine-Ruhr e Ranstad Holland, com alto

9. "Even if the Barca Report re-centred the debate on Cohesion Policies around the importance of highly localized factors conditioning success and failure, these results show that macro-national factors remain central. Macroinstitutional conditions and models of intervention make the difference in terms of impacts over and above the diversity of local conditions. Early strategic decisions - such as the early focus on innovation in Germany - have significant long-term consequences and are better taken at the national level with more complete information and foresight capabilities as well as more effective coordination" (Barca, 2009, p.14) 
grau de urbanização. São regiōes que se especializaram na produção de bens e serviços de elevada qualidade e valor. Determinadas regióes desse grupo apresentam elevada produtividade e altos salários. São regióes que atraem população. Trata-se do coração econômico da Europa. Embora apresentem alta performance econômica, algumas áreas apresentam elevadas taxas de desemprego. A indústria manufatureira de alta tecnologia representa o motor do crescimento.

As regiốes enquadradas no grupo de alta renda (AR) estão fora do eixo metropolitano e compreendem algumas cidades-polo. Estão fortemente localizadas na região dos Alpes. Trata-se de regiôes que apresentam altas taxas de emprego e forte crescimento da produtividade. Segundo os autores, dividem-se em dois grupos: regióes de maior e de menor nível de inovação.

O conjunto de regiôes definidas como de renda média (RM) divide-se em duas categorias: regiôes que perderam emprego na indústria e, também, população e as regióes que apresentam crescimento populacional. As primeiras são regiôes de crescimento populacional declinante cuja população apresenta níveis educacionais aquém das regiôes de altíssima e alta renda. As regióes na segunda categoria caracterizam-se por apresentar taxas de crescimento populacional positivas, como resultado da entrada de migrantes e cuja economia subsiste na base de serviços locais.

Finalmente, destacam-se as regióes de baixa renda (BR), localizadas no leste e no sul da Europa. De forma geral, apresentam reduzidas taxas de emprego, baixo grau de acessibilidade, reduzidos investimentos em pesquisa e desenvolvimento $(\mathrm{P} \& \mathrm{D})$ e baixa qualidade das instituições governamentais. O fato relevante está associado à heterogeneidade do grupo, posto que existem um conjunto de regióes caracterizadas como de baixa renda, concentradas na área central e oeste da Europa, e um segundo grupo caracterizado por regiôes de baixo crescimento econômico, localizadas nos limites sul da UE. O primeiro grupo destaca-se por ter uma população com níveis de educação bem acima da média das regióes de baixa renda, mas se defronta com perda de população, baixo nível de inovação e com uma renda $50 \%$ abaixo da média europeia. No outro extremo, destacam-se as regióes pobres e de baixo crescimento. Tal situação é explicada pelo baixo nível de qualificação e conhecimento dos residentes, que se reflete na ausência de capacidade dos empreendedores de assimilar inovação. 
Em síntese, os autores enfatizam, à luz de amplo escrutínio da literatura e apoiados em uma base de dados sofisticada, a existência de um processo de desigualdades regionais no território da União Europeia. Essas desigualdades, na percepção dos autores, se cristalizaram na geografia econômica da UE graças aos efeitos das economias de aglomeração, à difusão do conhecimento, à mobilidade do trabalho e à conectividade física. $\mathrm{Na}$ opinião dos autores, o conjunto de políticas de desenvolvimento regional desenhadas a partir dos pressupostos da teoria neoclássica do crescimento econômico não é capaz de reverter o processo de desigualdade. Eles argumentam que os paradigmas mais recentes, com destaque para a Nova Geografia Econômica (NGE), reforçam a tese da concentração, via economias de aglomeração, em vez da dispersão como pressuposto pelo modelo neoclássico de crescimento.

Os autores acreditam que é possível desenhar uma nova abordagem de desenvolvimento regional para as regiôes da $\mathrm{UE},{ }^{10}$ que reconheça as especificidades geográficas e econômicas de cada território, e que as estratégias e os instrumentos de políticas atendam às necessidades das diferentes regióes e que sejam capazes de promover a redução das desigualdades.

Um fato a destacar na análise dos autores é a ausência de qualquer menção ao relatório elaborado por Barca (2009), que introduz a discussão sobre a abordagem da base territorial.

Outra contribuição recente no âmbito da discussão da efetividade da Política de Coesão foi elaborada pelos pesquisadores Fiaschi, Lavezzi e Parenti (2018). Os autores operam com uma amostra de 175 regiōes de doze países da UE e analisam três períodos de programação dos fundos (1989-1993, 1994-1999 e 2000-2006). Estudam os

10. The place-sensitive distributed development approach we argue for here is consistente with all these frameworks, but modifies them in two ways. The first is based on realism about what factor mobility in the context of European integration can do for spreading wealth (...). The second limitation follows directly from this analytical framework: Europe-wide place-neutral for general-purpose policies cannot, in and of themselves, address the problems of spatially uneven development. This is why policies must be place-sensitive in the way we have defined. The specific mix and weight of instruments need to be tailored to the structural prospects of different kinds of European regions. Place sensitivity modifies the near-term way in which smart specialisation, structural funds, innovation strategies and institutional reforms are undertaken in the different regional groups. This pattern of divergente development is not a simple core-periphery geography, but rather one of structurally different groups of regional economies.

At the same time, many existing place-based approaches have become mostly bandaids for failing economic processes, as they do not mobilise the under-utilised human and other resources of the less-favoured regionsthe ultimate goal of place-sensitive distributed development is to combat the under-utilisation of regions' people and resources, so as to distribute development more widely. 
objetivos 1 e 2 da PC. Eles testam os impactos de todos os fundos no nível da Nuts de nível 2, que compreende as regiôes definidas entre 800 mil a 3 milhôes de indivíduos.

Operam com um modelo de crescimento de feiçóes neoclássicas, ao incorporarem uma matriz espacial para mensurar os impactos dos fundos estruturais no crescimento econômico nas regióes da amostra. Os resultados encontrados indicam a efetividade da Política de Coesão, no período 1989-2006, em dois aspectos: crescimento da competitividade regional captada mediante a elevação das taxas de crescimento do PIB por trabalhador; e redução das disparidades regionais. Os resultados das estimativas podem ser de grande valia no desenho da PC segundo a linha sugerida por Barca (2009). Os autores declaram que a proposta de Barca faz sentido e concluem, à luz dos resultados encontrados, que a Política de Coesão deveria sim focar em número restrito de prioridades centrais, dado que somente o Objetivo 1 e os outros fundos, não relacionados ao Objetivo 2 e ao FC, apresentaram efeito significativo. As estimativas do modelo sugerem que seja estimulada a concentração geográfica dos fundos em razão da presença de significativas externalidades espaciais positivas geradas pelos fundos.

Em sequência à apresentação de trabalhos acadêmicos que discutem o papel da PC no crescimento e no desenvolvimento dos países-membros da UE, destaca-se o trabalho de Falck, Koenen e Lohse (2019). Trata-se de contribuição inovadora, posto que os autores concentram sua atenção em programa específico nos limites de um país. Uma das preocupaçôes dos autores é investigar o "papel das políticas industriais na promoção do crescimento econômico em áreas atrasadas". Para tanto, eles avaliam a política de inovação implantada no território da Alemanha oriental, denominado Innovative Regional Growth Cores (IRGC). Esse é um programa criado pelo Estado alemão, destinado a intensificar os índices de inovação dos processos produtivos mediante um programa de subsídios a firmas selecionadas. O objetivo central é elevar o nível de eficiência das empresas receptoras de subsídios e, assim, aumentar a produtividade dos trabalhadores com rebatimentos positivos nos níveis de renda. A estratégia consiste então em promover um processo contínuo de inovação ao longo da cadeia de produção, que enseje a criação de novos produtos e novos processos de produçáo. Tornar as firmas mais competitivas, ampliando assim sua inserçâo no mercado global. Tais resultados serão alcançados por meio de um choque de inovaçáo nos processos de produção das firmas receptoras dos subsídios. As firmas escolhidas estão localizadas em regiôes de economia atrasada. Participam do programa 
as universidades, os centros de pesquisas e as organizaçóes não governamentais (ONGs), em parceria com as firmas receptoras.

Os resultados encontrados são positivos, pois a maioria das firmas subsidiadas aumentam as atividades em P\&D. Em segundo lugar, a política promove um aumento do nível de emprego entre as firmas receptoras e na região. Todavia, o modelo de análise não captou evidências do aumento do nível de bem-estar dos residentes nas regióes participantes do programa.

Pérez y Pérez e Calvo (2015) realizaram uma investigação sobre crescimento econômico e a questão da convergência na UE, fugindo dos padrões dos modelos neoclássicos ortodoxos, sempre apoiados em uma econometria sofisticada. Os autores estimaram o Índice Regional de Lisboa (IRL) ${ }^{11}$ para 265 Nuts, no período 2000-2010. Esse índice é construído a partir de um conjunto de oito indicadores, semelhante à técnica de construção do IDH proposto por Amartya Sen.

As estimativas englobando todas as regióes identificam uma melhoria do IRL entre o período 2000-2007. As regióes apresentaram um intenso crescimento do PIB per capita medido em PPC, entre 2000 e 2007. Durante a crise econômica do período 2007-2009, há declínio, seguido de retorno ao crescimento do PIB per capita, a partir de 2010. Foi observado a existência de um processo de convergência durante os anos de intenso crescimento. Durante os anos de crise (2007-2009), a trajetória do índice muda, o que sugere um processo de divergência.

A metodologia adotada pelos autores permite analisar a Europa (UE) de forma agregada e, também, segundo cada Estado-membro. Nessa oportunidade, foram escolhidos alguns países para testar os objetivos da PC. São investigados Alemanha, Reino Unido, França, Portugal, Irlanda, Espanha e Grécia.

11. "O Índice Regional de Lisboa (IRL) quantifica a coesão e sintetiza em um único valor a distância das regiões europeias em relação aos objetivos da Estratégia de Lisboa para 2010, bem como estima a distância entre as regiões. É composto de oito indicadores: i) taxa de emprego dos homens de 15-54 anos; ii) taxa de emprego das mulheres entre 15-54 anos; iii) taxa de emprego das pessoas entre 55-64 anos; iv) abandono escolar entre 18-24 anos; v) pessoas de 20-24 anos com pelo menos o estudo secundário; vi) participação em cursos permanentes de pessoas entre 25-64 anos; vii) gastos públicos em R \& D; viii) gastos privados em P\&D" (Perez y Pérez e Calvo, 2015, p. 4, tradução nossa). 
Países como Alemanha, Reino Unido, França, Irlanda, Portugal e Grécia apresentaram, em média, crescimento na renda per capita, mas houve, simultaneamente, divergência intrarregional. Somente a Espanha mostrou crescimento e convergência regional no período 2000-2007. Os resultados para cada país em relaçáo ao crescimento econômico versus coesão serão definidos a seguir.

No caso da Alemanha, as regiōes apresentaram aperfeiçoamento significativo no nível de desenvolvimento, porém sem melhorias no nível de coesão interna (desigualdade). As regióes da França apresentaram intenso desenvolvimento médio acompanhado de melhoria significativa da coesão inter-regional. Mas, segundo os autores, parte dos ganhos foram perdidos em função dos impactos da crise de 2008. No tocante ao Reino Unido, houve ganhos de desenvolvimento (coesáo) até 2005 e perda entre 2005 e 2010. Por sua vez, as desigualdades regionais cresceram durante todo o período 2000-2010. Quanto a Portugal, o nível de desigualdade inter-regional é elevado e muito acima dos países da amostra, e o padrão de desenvolvimento muito aquém dos objetivos de Lisboa. Em relação à Irlanda, os autores mostram que o país manteve, até 2007, bom nível de coesão interna (baixos níveis de desigualdade interna). Esse cenário muda a partir de 2008, por conta da crise, com aumento da desigualdade. Todavia, o país alcançou boa performance no que concerne aos objetivos de Lisboa. Finalmente, há o caso da Grécia, que apresentou trajetória decrescente a partir de 2005, em termos de tanto de desenvolvimento quanto de coesão interna.

Foi destacado em páginas anteriores que a UE é resultado de um amálgama de regiôes bastante heterogêneas, em termos de padrão de infraestrutura econômica, de níveis de renda e produto per capita, de nível de emprego, de estrutura produtiva, de níveis de conhecimento e da população. A problemática das desigualdades regionais é, pois, uma questão de Estado na UE. Quando um influente jornal europeu, de feição liberal na economia, afirma que "regional inequality is proving too polically dangerous to ignore", ${ }^{12}$ demonstra que os estudiosos da economia europeia estão na trilha correta.

Seguindo essa trilha de investigação, Percoco (2016) afirma que a efetividade da PC no crescimento do PIB per capita se mostra desigual no território, em função da heterogeneidade estrutural das regiōes. $\mathrm{Na}$ visão do autor, duas forças promovem essa

12. The Economist, 17 Dec. 2016, citado por lammarino et al. (2018). 
heterogeneidade: as diferenças nas estratégias de desenvolvimento adotadas pelos governos regionais e, em segundo lugar, o impacto dos programas no território, especialmente em um cenário caracterizado por grandes diferenças nas estruturas econômicas das regióes. A investigação do autor concentra-se em estudar como as estruturas econômicas locais podem influenciar o sinal e a magnitude dos resultados das políticas. Para verificar essa hipótese, o autor considera o setor de serviços como possível fonte de heterogeneidade. Ao contextualizar o papel dos serviços na economia da UE, o autor destaca que a Comissão Europeia, há décadas, tem estimulado a maior eficiência na indústria de serviços de transporte. Mais recentemente, tem dado grande apoio aos serviços culturais e àqueles intensivos em conhecimento, ao turismo e à inovação.

Assim posto, o autor procura avaliar a Política de Coesão em termos de Objetivo 1 (crescimento econômico) das regiốes Nuts-3 (regióes entre 150 mil a 800 mil habitantes) para o período 2000-2006. Ao utilizar modelagem e técnica econométrica espacial, o autor mostra que as transferências de recursos, por via da PC, promovem maior impacto econômico nas regiốes que apresentam setor de serviços mais atrasado, vis-à-vis as regióes de maior grau de desenvolvimento. $\mathrm{Na}$ opiniáo do autor, quanto maior o desenvolvimento desse setor, maior o crescimento da economia e, também, a capacidade que tem o setor de promover impactos positivos nos outros setores da economia.

Operando com um modelo neoclássico de crescimento, os autores Becker, Egger e Erlich (2018) procuram estimar o impacto dos fundos estruturais e do FC no processo de crescimento da UE. Foram escolhidos para análise os períodos de programação 19891993, 1994-1999, 2000-2006 e 2007-2013. O número de Nuts-2 estudadas foi de 187, 209, 253 e 253 para os respectivos períodos. Os autores procuram estimar os efeitos do objetivo 1 - também denominado objetivo de convergência - sobre o crescimento da renda per capita e do emprego. Estimam o modelo por meio de abordagem dos mínimos quadrados de dois estágios.

Os resultados encontrados indicam que o programa promoveu crescimento da região de programação. Todavia, os efeitos do programa perdem força quando a respectiva regiáo receptora alcança um novo patamar de desenvolvimento.

À luz das evidências apresentadas anteriormente, pode-se afirmar que a Política de Coesão alcançou seus objetivos: crescimento econômico acompanhado de melhorias 
das condiçôes de vida dos cidadãos dos Estados-membros da UE. Em ensaio bastante denso, Baleiras (2010) assim qualifica a PC:

A Política de Coesão tem um método próprio que é, em si mesmo, um arquétipo cultural de fazer política. Primeiro, sublinha a importância de haver objetivos claros e a ambição de alcançar resultados tangíveis, seja em termos de metas de desenvolvimento e de convergência real ou em planos comuns a outras políticas (...). Segundo, prossegue uma abordagem holística segundo a qual é no território que se encontram os vários impulsos desencadeados sobre os fatores de desenvolvimento (...).

Terceiro, o método desta política tem um valor acrescentado para a Europa na medida em que envolve os fazedores de desenvolvimento na montagem dos próprios instrumentos de intervenção, e não apenas na execução dos mesmos (...). Por fim, o seu método é ainda motivador para outras políticas, comunitárias ou nacionais, porquanto é rico e flexível: assenta em programaçóes estratégicas e operacionais multianuais, modelos de gestão orientada para o cumprimento de resultados e possui um quadro de avaliaçôes sistemáticas à concretização das programaçóes e dos objetivos de gestão (Baleiras, 2010, p. 4).

\section{A ABORDAGEM DA BASE DO TERRITÓRIO: A CONTRIBUIÇÃO DE BARCA (2009)}

Fabrício Barca, então ministro da Economia e Finanças da Itália, escreveu em 2009, com a ajuda de vários colaboradores, um relatório a pedido da Coordenadora da Política Regional da UE, em que lançou um novo conceito de política regional apoiado em uma nova abordagem denominada abordagem baseada no território (place-based approach). ${ }^{13}$

A primeira preocupação do autor é definir o que seja abordagem de desenvolvimento baseado no território. Trata-se de estratégia integrada de desenvolvimento, um modelo em que a unidade de intervenção é um território ou uma região definida endogenamente por meio do processo político.

13. "O chamado Relatório Barca - Barca (2009) - é, porventura, o documento mais completo e inspirador até à data quanto à racionalidade da Política de Coesão e às mudanças de direção a imprimir no ciclo de programação 2014/2020. Analiticamente muito robusto, o relatório propõe a concentração das intervenções em poucos bens públicos e a estruturação mais estratégica da governação, organizada segundo vários pilares" (Baleiras, 2010, p. 5). 
$\mathrm{Na}$ concepção de Barca, o modelo de política de desenvolvimento baseado no território, paradigma que a PC desejava implementar, era a forma moderna de promover o desenvolvimento. Era o único modelo disponível nesse estágio da UE, com a meta de cumprir a missão de desenvolvimento requerida para garantir sua própria existência. Seu objetivo era reduzir a armadilha da ineficiência e/ou a armadilha da exclusão social em locais específicos - atrasados ou avançados, urbanos ou rurais, centrais ou periféricos (Barca, 2009, p. 108). Esse modelo estava compatível com os objetivos do Tratado de Maastricht da UE, que estabelecia o desenvolvimento harmonioso e o enfrentamento das disparidades das regiōes e o atraso regional.

Em capítulo especial, o autor discute, de forma exaustiva, o sentido dos conceitos de eficiência e da igualdade (efficiency and equity), constantes do Tratado de Maastricht da UE e de elementos-chaves da Política de Coesão. O Objetivo 1 da PC explicita claramente essa questáo. $\mathrm{O}$ autor resgata os pressupostos dos paradigmas ortodoxos relacionados ao crescimento econômico e argumenta, ao citar vasta literatura, que o crescimento econômico não promove, de forma automática, a diminuição das desigualdades regionais. Antenado com as teorias antigas e novas, o autor mostra que "as economias de aglomeração" representam o único consenso na explicação do crescimento versus desenvolvimento. Mostra que o fenômeno da aglomeração não representa a panaceia para a questão das desigualdades regionais. Recorre aos pressupostos da NGE para destacar que, durante o processo de aglomeraçâo das atividades produtivas, surgem inúmeros problemas, capazes de obscurecer os efeitos positivos do processo. Entre os principais problemas, destacam-se: congestionamento do tráfego nas grandes cidades; crescimento dos preços da terra urbana; poluição; efeitos negativos na saúde das pessoas e no meio ambiente e na qualidade de vida; aumento nos custos da infraestrutura urbana; e tensôes sociais com elevação da taxa de criminalidade.

Avança com a discussão sobre eficiência, ao enfatizar que o papel da intervenção externa de origem pública pode, em determinadas circunstâncias, estimular a melhor e maior utilização dos fatores produtivos e, assim, promover o crescimento. Em outro ponto do relatório, chama atençáo para o papel das instituiçóes como promotoras do crescimento, resgatando as contribuiçôes de Douglas North. Destaca que não existe contradiçâo entre crescimento, base territorial e instituiçóes. Debate também a necessidade de intervençâo externa focada em uma cesta integrada de bens públicos e serviços. 
Concentração em uma cesta qualificada que minimize as falhas de mercado. ${ }^{14}$ Reforça a tese de que as intervençôes devem estar focadas no território (lugar ou região), contando com o envolvimento ativo dos atores locais.

$\mathrm{Na}$ discussão sobre igualdade, Barca (2009) lança a seguinte questão: como os governos deveriam perseguir os objetivos de Igualdade? Na sequência o autor questiona: por meio de uma simples transferência de recursos para pessoas ou por intermédio de uma política de desenvolvimento no território? O autor parte do pressuposto que desigualdade é um conceito multidimensional e que a variável renda, embora importante, não é o único componente na dimensão global da desigualdade. Na sua visão, o conceito de inclusão social é mais apropriado para analisar a questão da Igualdade. A ideia é que todos os indivíduos devem obter padrôes essenciais de vida e que as disparidades entre pessoas sejam aceitáveis desde que haja ampla participação e o processo seja justo. A política de inclusão social baseada no território pode ser definida como uma estratégia territorial para melhorar a inclusão social em suas várias dimensôes mediante a provisão de bens públicos e serviços, garantindo padrôes mínimos e melhorando o bem-estar social dos menos afortunados.

O autor enfatiza que não existe contradição entre alcançar bons níveis de eficiência e melhorar os padróes de inclusão social. Isso é possível, desde que exista uma boa governança.

Em seção especial, o autor, finalmente, destaca os princípios que inspiraram sua proposta, descritos a seguir.

1) Concentrar os recursos disponiveis - Concentrar a maioria dos recursos da $\mathrm{PC}$ em número reduzido de prioridades. Ele sugere inovação, migração, mudança climática, crianças, habilidades e velhice.

14. "The rationale for exogenous intervention suggests that it should not focus on financial transfers to firms and individuals but rather on the provision through conditional grants of integrated bundles of public goods and services. These comprise goods and services traditionally provided by the public sector due to market failure, such as law and order, education, training, basic research, water supply and waste disposal, business support, transport and healthcare. The peculiarity of the place-based approach is that they are provided in (integrated) bundles as a result of na exogenous intervention" (Barca, 2009, p. 25). 
2) Orientação das doaçóes dos Estados-membros para resultados - A ideia seria criar um plano estratégico para a UE, que aglutinasse as estratégias nacionais e regionais em torno de uma clara identificação de objetivos.

3) Mobilização e aprendizagem - Nesse item, a proposta consiste em agregar conhecimentos e identificar as preferências no nível do território. Mobilizar os atores locais, ao desencorajar a força dos rentistas. Criar um sistema de avaliação que permita identificar o que funciona.

4) Fortalecer o papel da Comissão Europeia da UE - Necessidade de investimentos em recursos humanos e reorganização interna são consideradas etapas fundamentais, como também sensibilizar os executivos, em todos os níveis, da UE.

5) Reforçar os freios e contrapesos politicos - $\mathrm{O}$ autor sugere a criação de um conselho específico para a PC e uma ligação formal, mediante adicionalidades financeiras, com o Pacto pela Estabilidade e Crescimento. Promover um debate no Parlamento europeu e no Conselho sobre os resultados da política (Barca, 2009, p. 11).

\section{LIÇÕES A INCORPORAR NO CASO DO BRASIL}

O modelo de política regional da UE apresenta grandes diferenças em relação ao caso brasileiro.

A UE, com a saída do Reino Unido (Brexit), é formada por 27 Estados-membros. Cada Estado com sua língua, seus valores e seus costumes, e todos esses aspectos foram respeitados no tratado de formação do bloco. As diferenças nos níveis de desenvolvimento e bem-estar social são significativas. As desigualdades estão presentes entre Estados e nesses Estados. Os recursos da UE advêm da contribuição dos Estados-membros, e cada Estado tem sua política de investimento. Os fundos estruturais e de investimento da UE são as principais fontes de recursos para a promoção do desenvolvimento de Estados e regiôes mais atrasadas. Pelo princípio da adicionalidade, um Estado-membro não pode substituir o orçamento próprio de investimento com os recursos dos fundos. $\mathrm{O}$ processo de alocação desses recursos segue uma lógica que respeita os princípios da PC. Esses princípios estão explicitados no Tratado de Maastricht da UE e são referendados por todos os membros. O território da UE está dividido em Nuts, que são unidades territoriais receptoras de recursos. A lógica do federalismo fiscal não opera no caso da UE. Os Estados-membros são autônomos em matéria de política fiscal, até determinado 
nível, mas não têm autonomia em matéria monetária. O Banco Central europeu tem o controle sobre a base monetária e administra a política monetária na UE.

No caso do Brasil, opera um federalismo clássico, com a presença de três entes federados: i) União; ii) estados; e iii) municípios. A Carta Magna de 1988 estabeleceu as responsabilidades e competências de cada ente federado. A União ficou com a responsabilidade das políticas monetária e fiscal. Aos estados e municípios foram vedadas açóes nessas duas áreas. Dada a notória desigualdade de renda e bem-estar social no Brasil, fenômeno que tem raízes históricas, os constituintes de 1988 criaram os fundos constitucionais de financiamento - FCFs (Fundo Constitucional de Financiamento do Nordeste - FNE, Fundo Constitucional de Financiamento do Norte - FNO e Fundo Constitucional de Financiamento do Centro-Oeste - FCO) e os fundos de desenvolvimento (Fundo de Desenvolvimento do Nordeste - FDNE, Fundo de Desenvolvimento da Amazônia - FDA e Fundo de Desenvolvimento do Centro-Oeste - FDCO). Existiam os fundos fiscais, pré-1988 (Fundo de Investimentos da Amazônia - Finam e Fundo de Investimentos do Nordeste - Finor), que estão em processo de extinção - de feição Regional (Amazônia, Nordeste e Centro-Oeste).

O objetivo fundamental era promover o desenvolvimento das regiôes atrasadas por meio de um aporte de recursos que seria insensível às variaçóes conjunturais da economia nacional. Tratava-se, na época, de mecanismo de transferência de certo percentual da receita global da União para compor os ativos dos fundos.

A política de desenvolvimento regional é de competência da Uniăo. Antes da Constituição Federal de 1988 (CF/1988) e da criação da PNDR, em 2007, já se fazia política regional no Brasil. ${ }^{15}$ No período 1959-1964, tem-se a fase do Grupo de Trabalho para o Desenvolvimento do Nordeste (GTDN), focada na regiáo Nordeste; no período 1964-1985, a fase dos governos autoritários, as intervençōes federais nas áreas periféricas do país estavam inseridas no Plano Nacional de Desenvolvimento (PND) I e II; no período pós-Constituinte (1988), a questáo regional (desigualdades regionais) torna-se objeto de preocupação das elites nacionais e é incorporada à agenda da política macroeconômica nacional.

15. Monteiro Neto et al. (2006) elabora uma síntese das transformações passadas e recentes na questão do desenvolvimento regional. 
O governo federal criou instância administrativa própria (ministério), com o objetivo de desenhar, implantar e operar açôes direcionadas no território nacional. A Superintendência do Desenvolvimento do Nordeste - Sudene, Superintendência do Desenvolvimento da Amazônia - Sudam e Superintendência de Desenvolvimento do Centro-Oeste - Sudeco foram agentes desse processo, ao desenharem e implantarem ações de desenvolvimento nas suas respectivas áreas geográficas, e os bancos estatais operaram como agências de fomento às atividades produtivas, tomem-se os exemplos do Banco do Nordeste - BNB e do Banco da Amazônia - Basa (Monteiro Neto e Porcionato, 2017).

No período 1959-1985, as regiōes periféricas mostraram forte dinamismo econômico, graças aos investimentos em infraestrutura econômica (modernização de portos, rodovias interestaduais e aeroportos, energia, comunicaçôes e irrigação rural), na promoção de industrialização substituidora de importaçóes e em outros empreendimentos em que as regióes possuíam vantagens comparativas. A presença do Estado - como investidor, empregador, facilitador e produtor - foi vital nesse processo de transformação. No caso da regiáo Centro-Oeste, destaca-se o papel dos investimentos em pesquisa e inovação, por intermédio da Empresa Brasileira Agropecuária (Embrapa), que promoveu a transformação da região, de uma grande área de pastoreio no maior polo agrícola da América do Sul. O caso da Amazônia é emblemático, com destaque para a implantação da Zona Franca de Manaus (Suframa), maior polo industrial da região, e o estabelecimento dos grandes polos minerais e de energia elétrica. O processo de industrialização provocou fortes efeitos de aglomeração, especialmente nas áreas urbanas metropolitanas. Houve, todavia, descaso em relação aos investimentos em bens públicos (água, esgotamento sanitário, habitação, urbanização, mobilidade urbana, creches e educação infantil), e os resultados são evidenciados pelas baixas taxas que caracterizam as estatísticas sociais.

Entre 1988 e 2002, os diferentes governos da União atuaram de forma diferenciada em relação à questão das desigualdades regionais. As ações de política para resolver problemas de desigualdades de renda e produto, no território de um país com dimensôes continentais como o Brasil, demandam um esforço de planejamento de longo prazo. Torna-se necessário, portanto, a construção de plano estratégico que incorpore açóes de médio e longo prazo. Infelizmente, durante o período 1988-1994, a agenda regional deixou de ser prioritária. 
A solução da crise do Estado de natureza macro (inflação, dívidas externa e interna, e crise fiscal) era questáo prioritária para o governo federal. A conjuntura econômica adversa demandava medidas de política econômica de curto prazo. As energias do governo central estavam centradas na soluçáo das questóes tipicamente de curto prazo, como inflaçáo crescente, crise no balanço de pagamentos, taxa de juros, mercado de trabalho e desequilíbrio fiscal. Os inúmeros planos de estabilização desenhados pelo governo federal durante o período 1986-1993 não lograram êxito na solução das sequelas da economia brasileira. O Plano Real de estabilização, implantado em 1994, promove, finalmente, certa estabilidade nos indicadores econômicos de curto prazo. Na sequência, foi desenhado e implantado um conjunto de reformas de caráter estrutural, com o objetivo de garantir a estabilidade macroeconômica do país. A reforma do Estado brasileiro constituía uma das mais importantes na cesta das inúmeras reformas projetadas pelo governo federal (cambial, comercial, de Estado e fiscal) e discutidas no parlamento brasileiro. O desenvolvimento de longo prazo do país carecia dessas reformas.

Observando-se os fatos econômicos que ocorreram no período 1986-1994, constata-se que não havia ambiente político, no nível do governo federal e até mesmo no Parlamento, para uma discussão sobre desenvolvimento regional que envolvesse políticas de longo prazo.

Com a nova administração federal (1995-2002), é lançado o Plano Brasil em Ação, em agosto de 1996. A estratégia desse plano não contemplava uma política explicita de desenvolvimento voltada para as regiôes mais atrasadas do país. O princípio básico do programa era enfrentar os problemas estruturais e sociais do país com açóes gerenciadas, em parceria com a iniciativa privada. $\mathrm{O}$ plano agrupava 42 empreendimentos, sendo 16 na área social e 26 na área de infraestrutura. $O$ objetivo era reduzir os custos na economia, propiciar aumento da competitividade do setor produtivo e melhorar a qualidade de vida da populaçáo (Brasil, 1998).

Somente na segunda metade da década de 2000, foi criada a PNDR, aprovada pelos membros do Congresso Nacional e chancelada pelo governo federal. No bojo da lei, existia a criação do Fundo de Desenvolvimento Regional. Os recursos do fundo seriam canalizados para apoiar açóes direcionadas a minimizar as desigualdades de renda e produto no território nacional. O fundo até a data presente (2020) não foi regulamentado, e assim nada foi implementado em bases duradouras. 
Os estados dispõem de autonomia para regionalizar seus territórios. A maioria já realizou essa tarefa. Os estados utilizam essa regionalização para alocar, no território, recursos de investimento. Esses recursos são oriundos de várias fontes: do orçamento fiscal estadual; de transferências governamentais oriundas da partilha de recursos da Uniáo; de empréstimos com o governo da União; e de empréstimos de instituiçôes nacionais e internacionais de fomento. Nesse último caso, o aval da União é crucial para a liberação dos recursos. Os Estados não fazem política regional.

As três instâncias de governo contam com a base de dados gerada pelo Instituto Brasileiro de Geografia e Estatística (IBGE), que é instituição federal oficial para geração de informaçóes demográficas e socioeconômicas. Trata-se de instituição com conceito internacional, responsável pela produção de dados quantitativos. Esses dados são obtidos a partir de pesquisas domiciliares e com os agentes produtores privados e órgáos da administração pública. Os censos demográficos e econômicos são realizados por essa instituição. Todos os indicadores de natureza econômica e social são coletados e divulgados pelo IBGE, que abastece os órgãos das diferentes instâncias de governo com informaçôes relevantes. Os agentes privados também contam com o apoio da fundação. No caso da União Europeia, existe o Eurostat. Fundado em 1953, é a autoridade estatística da UE. Tem como papel principal fornecer estatísticas às instituiçóes europeias, para que possam ser definidas e implementadas as mais variadas políticas comunitárias. Apresenta grande utilidade para as instituiçôes e os governos. Constitui uma importante base de dados para empresas, instituiçôes de ensino e pesquisa, bem como o público em geral.

O IBGE construiu uma regionalização do território nacional, dividindo-o em meso e microrregióes. A regionalização desse instituto precede qualquer política regional no país. O IBGE não faz política regional. A maioria dos estudiosos de economia regional utiliza a base de dados regionalizada da Instituição para desenvolver estudos acadêmicos. O Brasil, em matéria de base de informaçóes especializadas, encontra-se na fronteira do conhecimento. Tal evidência sugere que a construção de uma política regional que adote a abordagem da base territorial, sugerida por Barca (2009), não encontrará obstáculos em termos de informação.

Sintetizando, é possível então destacar as similitudes e as diferenças entre a política regional praticada na UE e a desenvolvida no Brasil. 


\subsection{Semelhanças}

\subsubsection{Regionalização do território}

No caso do Brasil, existe a divisão do território em meso e microrregiôes, definidas pelo IBGE. Em relação a UE, existem as Nuts, ${ }^{16}$ cuja base de dados é disponibilizada pelo Eurostat.

\subsubsection{As regionalizações dos Estados-membros}

$\mathrm{Na}$ UE, os Estados-membros realizam investimentos com recursos do orçamento nacional combinados com os recursos adicionais dos fundos da UE. Utilizam as Nuts como território de alocação dos recursos por razôes estratégicas. O princípio da adicionalidade funciona como regra de alocaçáo dos recursos no território.

Em relação ao Brasil, a regionalização concebida pelos Estados-membros tem objetivos econômicos e sociais. Na maioria dos casos, os administradores procuram identificar os principais gargalos econômicos e sociais na perspectiva territorial. Tal estratégia colabora na distribuição mais eficiente dos recursos próprios do orçamento para investimentos que, em sua grande maioria, são escassos. As administraçôes estaduais não fazem política regional. Observa-se, entretanto, que alguns Estados possuem agências de desenvolvimento que instrumentalizam programas de desenvolvimento no território. Essas agências são responsáveis pela operacionalização da política de incentivos fiscais à novas unidades produtivas no território estadual.

16. The Nomenclature of Territorial Units for Statistics (NUTS), established by Eurostat since the 1970s, was turned into Community legislation in 1988, when the reform of cohesion policy took place whereby the units were used for the allocation of large amount of resources. It is now ruled by EU Regulation 1059/2003 and subsequent amendments. The nomenclature is a hierarchical classification, whereby each Member State is subdivided into NUTS (level) 1 territories, each of which is subdivided into NUTS 2 territories, and so forth. Criteria for classification are the following: 1) administrative units within the Member State (defined as "a geographical area with an administrative authority that has the power to take administrative or policy decisions for that area"); 2) thresholds of population (level 1: 3-7 million; level 2:800 thousand - 3 million; level 3: 150-800 thousand); 3) if no administrative units exist for that level (population interval), this NUTS level shall be constituted (as a non-administrative unit) "by aggregating an appropriate number of existing smaller continuous administrative units" taking into consideration "geographic, socio-economic, historical, environmental circumstances" (thresholds will not be binding) (Barca, 2009, p. 61). 


\subsubsection{Planejamento estratégico}

Considerando-se a literatura consultada e as contribuiçóes de Barca, é possível destacar a preocupação, tanto dos administradores dos Estados-membros quanto dos executivos da UE, com a questão da eficácia na alocação dos recursos, assim como em relação à mensuração dos impactos das açôes no território. Há grande preocupação das autoridades em incentivar a participaçáo dos diferentes grupos sociais das comunidades receptoras no que concerne à aplicação dos recursos dos fundos. Tenta-se, de toda forma, evitar a ação dos rentistas locais.

Em relação ao Brasil, observa-se um esforço dos membros subnacionais em operar com planejamento estratégico no processo de alocação dos recursos próprios do orçamento estadual. Existem os órgáos de controle (tribunais de conta estaduais) que fiscalizam as açóes dos agentes públicos.

Muitos agentes subnacionais já adotam a prática de apresentar e discutir com os membros das comunidades, em reunióes públicas, abertas a todos os estratos sociais, as açôes que pretendem desenvolver em determinada regiáo, ou territórios de seus Estados. Trata-se de estratégia louvável e politicamente correta, mas por conta da escassez de recursos, as açóes apresentam uma escala reduzida e seus impactos são de pequena monta. Algumas administraçóes estabelecem metas quantificáveis, mas o estudo de impactos, no nível dos entes subnacionais, não é realizado, ou, quando o é, sua publicização é bastante modesta.

No tocante ao governo federal, sabe-se que a prática de avaliação existe e está em operação em alguns setores da administração. Todavia, essa prática é recente.

O governo federal desenhou e implantou uma política de avaliação e impactos dos instrumentos da PNDR (Resende e Monteiro Neto, 2016). O Ministério da Integração Nacional (MI) estabeleceu, em 2013, um acordo de cooperação técnica com o Ipea, órgão de pesquisa do governo federal, para realizar a avaliação. As avaliaçóes concentram-se nos fundos constitucionais, e as já realizadas compreendem o período 1995-2015.

A PC da UE, chancelada por todos os Estados-membros, apresenta um desenho que se assemelha a um plano estratégico. Princípios e objetivos estão claramente definidos. 
Os fundos possuem regulação específica. O que financiar, onde financiar e o público beneficiado são itens que estão claramente regulados e explicitados.

No caso do Brasil, a PNDR contempla princípios e objetivos que envolvem todo o território do país. Sucede que os recursos não reembolsáveis, oriundos do orçamento federal, são bastante reduzidos diante das necessidades quase que ilimitadas, especialmente das regiōes mais atrasadas. Os fundos constitucionais são administrados pelos agentes financeiros. Os planos de trabalho desses agentes dialogam com a PNDR.

\subsection{Diferenças}

\subsubsection{Fundos de desenvolvimento}

Como foi destacado em seção anterior, o Tratado de Maastricht da UE criou cinco fundos (estruturais e de investimento) responsáveis pela operacionalização da PC. Cada fundo tem sua área de atuação claramente explicitada no regulamento aprovado pelo Parlamento europeu. Em tabela especial, o relatório de Barca (2009, p. 67) apresenta as diferentes categorias de intervenção segundo o escopo de cada fundo. Somente em quatro categorias de política, existe superposição de ação dos fundos: transporte, energia, proteção ambiental e prevenção de risco, que são atividades financiadas pelo Fundo Regional e pelo Fundo de Coesão, concomitantemente. Também a política de assistência técnica está presente na regulação dos três fundos (Regional, Social e de Coesão).

Em relação ao Brasil, a situação é totalmente diversa. Segundo Monteiro Neto et al. (2016), desde 2007, opera a PNDR I, aprovada pelo Congresso Nacional. Tal política teve

inspiração na experiência regional da União Europeia, cuja ênfase estava na compreensão multiescalar da dinâmica territorial e na noçâoo de identificação e fortalecimento das vantagens competitivas regionais. A PNDR tem como objetivo a redução das desigualdades de nível de vida entre as regiôes brasileiras e a promoçáo da equidade no acesso a oportunidades de desenvolvimento, e deve orientar os programas e as açóes federais no território nacional (Monteiro Neto et al., 2016, grifo nosso).

Para viabilizar os objetivos da PNDR, foi proposto o Fundo Nacional de Desenvolvimento Regional (FNDR), que nunca foi implantado. A ausência desse fundo constitui o mais sério obstáculo à plena operacionalização da PNDR. Atualmente, os recursos 
disponíveis advêm dos fundos constitucionais e são claramente insuficientes para o cumprimento dos objetivos propostos pela política.

\subsection{Transparência na aplicação dos recursos}

$\mathrm{Na}$ UE, as políticas e as açôes são realizadas com a plena participação da Comissão Europeia, de Estados-membros e de conselhos regionais. O orçamento da UE é discutido e aprovado no Parlamento, com a participação de todos os representantes dos 27 Estados-membros, escolhidos por meio de eleição direta pelos residentes de cada Estado-membro. As comunidades beneficiadas possuem amplo conhecimento das açóes realizadas.

Em relação ao Brasil, existe uma articulação entre o atual Ministério do Desenvolvimento Regional (MDR), ex-Ministério da Integração Nacional, e os entes subnacionais em algumas açóes de política. Mas essa articulação é tímida, e o MDR tenta avançar nessa questáo.

\subsubsection{Definição de prioridades}

O estabelecimento de prioridades no território da UE está definido desde a criação da PC. Remonta a 1973, com a criação do Feder. Sáo quase cinquenta anos de operação de política regional explícita. Nos primórdios, as necessidades eram gigantescas. Isso exigiu da Comissão Europeia uma ação em várias frentes, com ampla pulverização das atividades e, por consequência, dos recursos. Na medida em que os gargalos eram equacionados, a agenda de ações era redesenhada com diminuição da dispersão. Barca (2009) sugere em seu relatório, que a Comissão Europeia da UE concentre os recursos em quatro prioridades. ${ }^{17}$

Os europeus alcançaram um padrão civilizatório invejável, que é mimetizado pela maioria das nações do mundo. Universalizaram a oferta de água potável, esgotamento sanitário, energia elétrica na cidade e no campo, educação básica, transporte público urbano e comunicaçóes, constituindo assim uma cesta de bens públicos de alto valor agregado. Os efeitos multiplicadores dos investimentos nessa pletora de bens públicos

17. Barca (2009, p. 156) afirma de forma explícita: "Focusing resources on core priorities: a large share of cohesion policy resources should be concentrated on 3-4 narrowly defined core priorities of EU interest". 
podem ser aquilatados por intermédio do crescente número de turistas estrangeiros que visitam a regiáo gerando emprego, renda e divisas para os Estados-membros.

No caso do Brasil, a questão a ser feita é: faz sentido concentrar os recursos em quatro ou cinco açóes, como política explícita da PNDR? A resposta pode ser não e sim. Tudo é uma questão de prazo.

A PNDR (objetivo 1) persegue o aumento do PIB per capita das regióes mais atrasadas a taxas mais elevadas vis-à-vis as regióes mais desenvolvidas. Isso promoverá a convergência e ensejará também o aumento do emprego e, consequentemente, o incremento da renda dos residentes.

Sucede, todavia, que as regióes atrasadas apresentam um deficit estrutural de bens e serviços de infraestrutura, que opera como fator obstaculizador ao crescimento elevado e persistente do PIB per capita. A literatura especializada mostra que a ampliação do estoque de infraestrutura promove aumentos significativos na produtividade dos fatores. Diante desse cenário, pode-se inferir que investimentos destinados aos serviços de infraestrutura econômica e social nas regióes atrasadas constituem um passo fundamental para eliminar a armadilha de crescimento e desenvolvimento dos referidos territórios.

Essas carências, para serem equacionadas, exigem dos agentes públicos, especialmente do governo da União que detém a maior fatia do orçamento global, um esforço elevado no desenho de políticas e ações para solucionar esses gargalos. Essas são ações de longo prazo.

Os agentes públicos federais possuem pleno conhecimento dessas carências e da importância desse tipo de investimento na promoção do crescimento e desenvolvimento.

Seria possível escolher quatro ou cinco açóes de políticas com vistas a ampliar a oferta de bens e serviços de infraestrutura? Quais? Onde? Qual o público-meta? A resposta é sim.

Em função da carência estrutural de recursos orçamentários do MDR para açóes no território, a estratégia que ensejaria a maior otimização de resultados para a PNDR seria concentrar os recursos nos territórios mais atrasados, ao focar nas famílias mais pobres e 
canalizar recursos para açóes em setores que apresentam elevado multiplicador de renda e emprego, no curto prazo, como estradas, água encanada, energia elétrica e comunicações.

A maioria dos territórios das regióes atrasadas apresenta elevado potencial econômico em diversos setores da matriz produtiva. Agricultura irrigada em área de sequeiro, pequena indústria de processamento, turismo rural, serviços urbanos especializados e sistemas agroflorestais são exemplos de empreendimentos já em franca operação nesses territórios, mas que se defrontam com barreiras para ampliar a escala dos negócios, em razão da carência de determinados serviços de infraestrutura. Essa carência representa uma verdadeira armadilha para o crescimento.

A escassez de recursos do governo federal, oriundos do orçamento fiscal, constitui, portanto, o principal óbice para a solução da carência de infraestrutura. Contudo, alguns tipos de serviços elencados anteriormente possuem interface com o setor privado. Um marco regulatório bem desenhado pode contribuir para a solução desse problema.

\section{POLÍTICA DE COESÃO VERSUS PNDR: UM CONTRAPONTO}

Nesta seção, procura-se comparar as principais singularidades dos desenhos das políticas regionais da UE e do Brasil (PNDR), a partir da mudança de modelo de desenvolvimento regional proposto por Barca (2009).

Fundamentalmente, Barca (2009) propóe uma nova abordagem da política de desenvolvimento para a UE - isto é, um redirecionamento da PC, ${ }^{18}$ aprovada nos tratados dos anos 1980. Trata-se de política de desenvolvimento voltada para o território (place-based approach), capaz de associar objetivos econômicos - como eficiência e crescimento econômico -, com objetivos sociais - como igualdade -, explicitados nos primeiros artigos introdutórios do tratado de formação da União Europeia, já amplamente discutidos em seções precedentes.

18. Barca assim define "Cohesion" is the means through which the Treaty commits the Union to pursue harmonious development and reduction of disparities. It should do so, as a complement to Member States' "conduct" and "coordination" of their economic policies, both by taking those tasks into account when formulating and implementing other policies and the internal market and, directly, through the use of dedicated Funds." The general reference to the action and condition of fitting together, embodied in the word "cohesion", is qualified by the Treaty through specific reference to three dimensions: "economic", "social" and (in the draft new Treaty explicitly) "territorial" (Barca, 2009, p. 3, grifo nosso). 
A grande preocupação de Barca (2009), ao desenhar uma nova política de desenvolvimento coerente com os princípios da PC, foi juntar a trilogia eficiência-equidade-territorialidade em apenas uma proposta de política de desenvolvimento. Eficiência está associada ao crescimento econômico, com a promoção de processo de convergência do PIB per capita entre os Estados-membros. Equidade está relacionada à inclusão social da população, ao promover a diminuição da desigualdade de renda e a melhoria do bem-estar social. Finalmente, a questão do território, com a destinação dos recursos do orçamento da Uniāo, preferencialmente em regióes mais atrasadas do território. Para o autor, a abordagem baseada no território satisfaz os três princípios, sem que haja incompatibilidade de sua aplicação simultânea.

Em capítulo especial, ao cotejar a política regional dos Estados Unidos com a política da União por meio de um breve resgate histórico, o autor chama atenção para as singularidades das duas políticas. ${ }^{19} \mathrm{O}$ desenho institucional, por ser diferente, implica estratégias de intervenção diferenciadas. Todavia, a importância e o papel do território estão presente em ambas as políticas. No caso dos Estados Unidos, remonta à década de 1930, com a política do New Deal. O exemplo do Tennesse Valey Authority (TVA) é uma experiência clássica. Os Estados Unidos representam um desenho de federalismo de cooperação, no qual o governo federal construiu políticas de desenvolvimento que englobam todo o território nacional, que respeitam a autonomia dos estados-membros, que competem entre si. No caso da UE, a situação política é mais complexa, posto que a União não é um Estado, e sim uma instituição que congrega Estados-membros autônomos e independentes.

O quadro 1 apresenta os dez pilares da reforma da governança da PC proposta pelo autor, que os define como princípios. Trata-se de propostas de política de desenvolvimento que estão coerentes com o desenho político/institucional da UE, como instituição que

19. "The fact that the governance of the two development budgets differs is in line with what might be expected in view of the different development stages of the two Unions. The Federal government of the US is the result of a choice made more than two centuries ago by similar-minded communities. Though almost permanently contested, it is strengthened as regards development by the long-term effects of the "New Deal", and it has a high degree of legitimacy to manage directly a large amount of resources for development and to intervene directly in regions. The hybrid government of the $E U$ is the result of a relatively recent choice made by very dissimilar communities which have been in conflict for centuries. It does not have federal powers and very different views coexist on what the limits of its powers should be. It largely relies on lower levels of government to allocate resources for development, establish priorities and manage spending" (Barca, 2009, p.13, grifo nosso). 
administra um orçamento composto por contribuiçôes dos Estados-membros - com base no seu PIB -, pelos direitos aduaneiros e por uma porcentagem das receitas do imposto sobre o valor agregado (IVA) de cada país, em que os Estados-membros dispóem de autonomia política para manejar seus orçamentos próprios e do fundo, sujeitos a um conjunto de condicionalidades.

Os princípios de Barca (2009) não estão descolados dos objetivos maiores da Política de Coesão. Pelo contrário, o autor desenha um novo cenário que intenta maximizar os resultados da PC, graças a novas práticas de governança.

Barca (2009), além de elencar os pontos positivos da Política de Coesão, também destaca as fraquezas e falhas da política, que, nas suas palavras, devem ser atribuídas ao processo de negociação que define as questôes de governança e metas após a discussão dos recursos.

O relator identifica sete problemas como os mais significativos, conforme a seguir descritos.

1) Não existe entre as altas autoridades da UE um compromisso com um modelo de política de desenvolvimento. As estratégias, tanto no nível da UE quanto dos Estados-membros (regiôes), carecem de objetivos claros e de justificativa de como as intervençôes planejadas devem ser alcançadas.

2) A percepção dos agentes públicos sobre a abordagem baseada no local e no território é confusa. Os agentes dão pouca atenção ao conhecimento local e às preferências dos residentes.

3) Os objetivos e as metas de eficiência e equidade são geralmente misturados, o que reduz o espaço para a análise de desempenho.

4) O sistema de condicionalidades não é suficientemente orientado para os resultados e apresenta-se ineficaz.

5) A mobilização dos atores locais e a abordagem experimental são inadequadas. A ausência de debate público combinado com gestáo de cima para baixo prejudica o sentido das políticas baseadas no território e abre espaço para a ação dos rentistas.

6) Embora tenham ocorrido progressos na cultura de avaliação, não foi criado um modelo para analisar as questōes relacionadas ao que funciona e para quem funciona no contexto das políticas. 
7) Fora da comunidade que trata da PC, não existe um debate político de alto nível contínuo sobre essa política e seus resultados, quer no Parlamento europeu, no Conselho, na Comissão Europeia ou na sociedade em geral, e não há ligação com debate sobre crescimento e estabilidade.

QUADRO 1

União Europeia: os dez pilares da reforma da governança

\begin{tabular}{|l|l|}
\hline Pilares & \\
\hline 1 & Uma concentração inovadora nas prioridades centrais e uma alocação territorial conservadora \\
\hline 2 & Um novo quadro estratégico para a PC \\
\hline 3 & Uma nova relação contratual, implementação e reporte com vistas a resultados \\
\hline 4 & Uma governança fortalecida para as principais prioridades \\
\hline 5 & Promover gastos adicionais, inovadores e flexíveis \\
\hline 6 & Promover experimentalismo e mobilizar atores locais \\
\hline 7 & Promover o processo de aprendizagem: um movimento em direção à avaliação de impacto prospectiva \\
\hline 8 & Reorientar e reforçar o papel da Comissão Europeia como centro de competência \\
\hline 9 & Desenhar uma gestão e um controle financeiro \\
\hline 10 & Reforçar o sistema político de alto nível de freios e contrapesos. \\
\hline & $\begin{array}{l}\text { Fonte: Barca (2009). Tradução nossa. } \\
\text { Elaboração do autor. }\end{array}$
\end{tabular}

Sem embargo, a PNDR foi concebida no bojo de um marco institucional diferente do desenho político/institucional europeu. Tanto bo caso do Brasil, como no dos Estados Unidos, o modelo de Estado é federalista. Segundo a CF/1988, a Federação é formada pelo governo federal, estados e municípios. Segundo interpretação de Ismael, o modelo federalista "é marcado por algumas ambiguidades recorrentes, quais sejam unidade versus diversidade, centralização versus descentralização, forças centrípetas versus forças centrífugas e cooperação versus competição” (Ismael, 1990, p. 10). Na interpretação de Ismael, o federalismo cooperativo brasileiro remonta a 1945, "no qual o governo federal ampliou sua intervenção no território nacional com o objetivo de reduzir as desigualdades entre as regiôes brasileiras" (op. cit., p. 14) e terminou com o regime militar de 1964. Não obstante outras questóes, o autor destaca que o federalismo brasileiro, a partir de 1988, apresenta um desenho tipicamente do tipo competitivo-cooperativo. Os estados e os municípios competem entre si. O governo federal, por meio das políticas de transferência entre os estados e municípios, apresenta dinâmica claramente cooperativa. 
A PNDR é resultado dessa noção de cooperação. Bacelar (1999), ao identificar um conjunto de forças internas e externas ao país que estavam contribuindo para a fragmentaçáo da economia nacional, clamou pela necessidade da construçáo de uma política nacional de desenvolvimento regional capaz de abarcar todo o território do país. Após um longo debate com as esferas dos poderes Legislativo e Executivo, posto que os argumentos de natureza econômica eram táo clarividentes à época, as ideias de Bacelar tornaram-se realidade com a institucionalização, em 2007, da PNDR (Brasil, 2019) que já se encontra em sua terceira versáo.

A PNDR nacional foi claramente inspirada no modelo da UE, ${ }^{20}$ ao contemplar objetivos, eixos e estratégias, direcionados para as questóes de eficiência econômica e equidade associadas a uma dimensão multiescalar no território. Visto hoje em uma perspectiva de macro política, as duas políticas de desenvolvimento de natureza territorial são extremamente semelhantes.

\subsection{Princípios versus objetivos}

Ao se cotejar os princípios da nova Política de Coesão (tabela 1) com os objetivos prioritários da PNDR (2019), elencados no quadro 2, percebe-se quão convergentes estes são. ${ }^{21}$

A caracterização das prioridades 1 e 4 da PNDR, apresentadas no quadro 3, estão presentes nos pilares 1 e 3 da Política de Coesão - tabela 1, explicitados e amplamente comentados por Barca (2009). Convergência está para a PNDR assim como eficiência está para a PC. Embasado em uma vasta literatura, Barca (2009) destaca que é possível ter crescimento econômico (eficiência), definido aqui como a melhor utilizaçáo dos recursos produtivos subutilizados pelo sistema, sem que seja possível

20. Monteiro Neto et al. (2017, p. 40) afirma: "Com inspiração na experiência regional da União Europeia, cuja ênfase estava na compreensão multiescalar da dinâmica territorial e da noção de identificação e fortalecimento das vantagens competitivas, a nova política regional - PNDR - ganhou vida própria em 2007".

21. 0 autor deste trabalho procurou apresentar as principais linhas básicas das duas políticas por intermédio de formato de quadros, a fim de tornar a leitura mais compreensivel ao leitor e colaborar ao processo de análise e discussão. 
alcançar convergência. ${ }^{22}$ Equidade é um elemento-chave da PNDR, enquanto inclusão social é um objetivo crucial da PC e, por rebatimento, da política de desenvolvimento baseada no território proposta por Barca (2009).

Situação semelhante dá-se para as prioridades 2 e 4 da PNDR. Estas estão contidas nos pilares 1 e 2 (quadro 1) da proposta do relator. Ambas estão associadas ao objetivo da eficiência da PC.

\subsection{A escolha das prioridades}

Antes de adentrar na análise das políticas, torna-se importante destacar que todas as propostas de política sugeridas por Barca (2009) são derivadas dos dez pilares apresentados no quadro 1.

Barca (2009) ${ }^{23}$ elabora uma profunda reflexão sobre a necessidade de concentrar os recursos do orçamento da União (fundos) em um conjunto restrito de bens e serviços públicos. A pulverização dos recursos, em determinados casos, não tem se mostrado eficiente e eficaz na solução dos problemas econômicos e sociais. Essa proposta de política está presente no pilar 1 . O autor destaca três pontos:

22. "The seventh misconception is that "convergence" of per-capita income or per capita GDP among places and regions is an objective of place-based development policies which captures their ultimate aim well. This is not the case. "Convergence" is neither a necessary nor a sufficient condition for policy success in pursuing either the efficiency or social inclusion objective, and is a misleading label. (Barca, 2009, p. 38). Convergence is not a necessary condition for increasing efficiency. A successful reduction of capacity under-utilisation in lagging regions can take place at the same time as prosperous agglomerations grow faster and disparities between the centre and periphery widen. On the other hand, convergence might occur as a result of a "race to the bottom", with policy failing to have any positive effect in lagging regions and GDP declining in the more prosperous ones" (Barca, 2009, p. 30).

"As regards the social inclusion objective, convergence is only one of several relevant factors. First of all, income per capita needs to be distinguished from GDP per capita: convergence of the latter does not necessarily imply convergence of the former, due to commuting or transfers. Secondly, convergence of regional per-capita income might occur, but because of rising interpersonal inequalities within regions, overall inequality might increase. Indeed, empirical evidence shows, as noted above, that overall inequality is dominated by inequalities within regions rather than between them 123 . Third, income is only one of several dimensions against which social inclusion needs to be assessed and convergence of income need not entail convergence of these other aspects." (op.cit., p. 40).

23. "The first change proposed is the concentration of resources on a limited number of priorities which has expectation that positive results will be achieved, so encouraging increased involvement. Third, the concentration would require (and enable) the Commission to focus its human resources on a few issues, giving more credibility to its strategic role of governing cohesion policy" (Barca, 2009, p. 17). Eluded reforms in the past. This would have several positive effects. First, it would create a Europe-wide critical mass of interventions in a few policy areas, capable of having na impact on issues of European-wide relevance. Second, the effective delivery of the measures concerned should attract both public and high-level political attention (...)" . 
three criteria are of particular importance to apply when selecting the core priorities: 1. Its EUwide relevance; 2. Its place-based nature; 3. Its verifiability (Barca, 2009, p. 111).

Após uma detalhada reflexão sobre a importância de concentrar as açóes em um número reduzido de bens e serviços públicos, o autor chega à definição das prioridades. O quadro 2 apresenta o elenco de seis prioridades. A importância da escolha está amplamente justificada no corpo do relatório. Observa-se que duas prioridades estão associadas ao objetivo de eficiência (convergência); outras duas prioridades se relacionam com o objetivo de equidade (inclusão social); e, finalmente, duas prioridades cujos objetivos de eficiência e equidade se superpóem.

QUADRO 2

Brasil: PNDR (2019)

\begin{tabular}{|l|l|}
\hline Prioridades & \multicolumn{1}{c|}{ Objetivos prioritários } \\
\hline 1 & $\begin{array}{l}\text { Promover a convergência dos níveis de desenvolvimento e de qualidade de vida inter e intrarregiões brasileiras e a equidade no } \\
\text { acesso a oportunidades de desenvolvimento em regiões que apresentem baixos indicadores socioeconômicos. }\end{array}$ \\
\hline 2 & $\begin{array}{l}\text { Consolidar uma rede policêntrica de cidades, em apoio à desconcentração e à interiorização do desenvolvimento regional e do país, } \\
\text { que considere as especificidades de cada região. }\end{array}$ \\
\hline 3 & $\begin{array}{l}\text { Estimular ganhos de produtividade e aumentos da competitividade regional, sobretudo em regiões que apresentem declínio popula- } \\
\text { cional e elevadas taxas de emigração. }\end{array}$ \\
\hline 4 & $\begin{array}{l}\text { Fomentar agregação de valor e diversificação econômica em cadeias produtivas estratégicas para o desenvolvimento regional, } \\
\text { observando-se critérios como geração de renda e sustentabilidade, sobretudo em regiões com forte especialização na produção de } \\
\text { commodities agrícolas ou minerais. }\end{array}$ \\
\hline
\end{tabular}

Fonte: MDR, 2020

A PNDR do Brasil, por sua vez, contempla seis eixos setoriais conforme apresentado no quadro 5 . A fim de comparar com a categorização dos objetivos da Política de Coesão da UE (place-based - approach), o analista procura associar a definição de setores da PNDR com a definição de objetivos da PC em termos de objetivos: eficiência e equidade. Trata-se de estratégia de análise com vistas a comparar as propostas de ações das duas políticas regionais. 
QUADRO 3

Política de Coesão: principais prioridades - Proposta de Barca (2009)

\begin{tabular}{|l|l|l|}
\hline Número & \multicolumn{1}{|c|}{ Especificação } & \multicolumn{1}{|c|}{ Objetivos1 } \\
\hline 1 & Inovation & Eficiência \\
\hline 2 & Climate Change & Eficiência \\
\hline 3 & Migration & Inclusão social (equidade) \\
\hline 4 & Children & Inclusão social (equidade) \\
\hline 5 & Skills & Eficiência/equidade \\
\hline 6 & Ageing & Eficiência/equidade \\
\hline
\end{tabular}

Fonte: Barca (2009, p. 111)

Nota: ${ }^{1}$ Associados à PC.

À luz da classificação proposta por Barca (2009), pode-se afirmar que a maioria dos setores que compóem os eixos setoriais da PNDR está correlacionada aos objetivos do crescimento econômico (eficiência). Os dois primeiros eixos da PNDR estão associados tanto à melhor utilização dos fatores produtivos subutilizados que operam no sistema, quanto à maior agregação de capital físico e humano que se manifesta por meio da maior incorporação de tecnologia e inovação nos processos produtivos. A hipótese da convergência pode ser um resultado natural dos efeitos das políticas setoriais apresentadas nos eixos 1 e 2, dependendo das características econômicas do território. Quanto mais atrasada a região/território vis-à-vis as desenvolvidas, maior a probabilidade de o processo de convergência do PIB instalar-se no sistema econômico.

O eixo 3 da PNDR apresenta dupla correspondência, no sentido que pode promover melhorias na eficiência do sistema econômico e, concomitantemente, aprofundar o processo de inclusão social. Investimento em capital humano contribui para gerar incrementos líquidos no nível de produto bruto e na renda dos trabalhadores. Incrementos substanciais de produtividade colaboram para aumentos de ganhos de renda real da força de trabalho. Elevação no nível de conhecimento dos trabalhadores estimula a incorporação de novas tecnologias por parte do empreendedor e promove a inovação. Esse processo, do tipo circular e acumulativo, resulta em maior nível de produto per capita e maior renda per capita. Os proprietários dos fatores de produção (capital e trabalho) são duplamente beneficiados. Eficiência e inclusão social são gêmeos siameses nesse processo. 
QUADRO 4

PNDR: eixos setoriais - Brasil

\begin{tabular}{|l|l|l|}
\hline Eixos & \multicolumn{1}{|c|}{ Setores } & \multicolumn{1}{|c|}{ Categorização dos objetivos } \\
\hline 1 & Desenvolvimento produtivo & Eficiência \\
\hline 2 & Ciência, tecnologia e inovação & Eficiência \\
\hline 3 & Educação e qualificação profissional & Eficiência/inclusão social \\
\hline 4 & Infraestruturas econômica e urbana & Eficiência \\
\hline 5 & Desenvolvimento social e acesso a serviços públicos essenciais & Inclusão social \\
\hline 6 & Fortalecimento das capacidades governativas dos entes subnacionais & Eficiência \\
\hline
\end{tabular}

Fonte: MDR, 2020.

Os eixos 4 e 6 da PNDR também perseguem o objetivo da eficiência. Em um país com tamanha carência de infraestrutura econômica, especialmente nas regióes mais atrasadas, fato já comentado em seção precedente, torna-se redundante aprofundar qualquer discussão sobre o assunto. $\mathrm{O}$ eixo $6 \mathrm{da}$ política tem forte rebatimento sobre a eficiência do sistema, posto que destaca a questão da governança no nível de estados e municípios. A ação desses agentes governamentais é crucial para o êxito ou o insucesso de açôes e programas desenhados pela PNDR. Os mecanismos cooperativos presentes nessa política dependem da boa governança dos agentes subnacionais. ${ }^{24}$

Os eixos setoriais da PNDR diferem em larga medida das principais prioridades (core priorities) propostas por Barca (2009) em relação à União e elencadas no quadro 2. Tal contraste é resultado das elevadas diferenças no nível de desenvolvimento econômico e social alcançado pelos dois territórios. A PNDR, na sua nova versão de 2019 (Brasil, 2019), apresenta um conjunto de objetivos compatível com as necessidades das regióes mais atrasadas do país.

A Política de Coesão da UE, por intermédio de seus fundos estruturais, operando de forma contínua e sustentada, foi capaz - em período de aproximadamente cinquenta anos - de universalizar uma pletora de bens e serviços públicos. Entre estes, pode-se elencar: água encanada e tratada; esgotamento sanitário tratado; tratamento dos resíduos sólidos; energia elétrica em todos os rincôes dos Estados-membros; rodovias transnacionais de alto padrão de qualidade que conectam as principais aglomeraçôes urbanas da

24. Para mais detalhes, ver Linhares, Mendes e Lassance (2012). Os autores debuxam, com propriedade, em alguns artigos, as principais causas de êxitos e fracassos das ações de políticas públicas no nível dos agentes subnacionais. 
União; redes de transporte público, do tipo ferroviário, que ligam os principais centros urbanos; transporte público de massa, do tipo rodoferroviário nas principais RMs dos Estados-membros; e educação primária e secundária universalizada. Essa maior oferta de bens e serviços públicos representa uma pequena amostra do sucesso da PC. ${ }^{25}$

A tabela 2, retirada de Barca (2009), mostra que os fundos (cinco), que dão suporte à Política de Coesão, alocam recursos em todos os elos da matriz econômica e social da UE. Observe o leitor que existem os segmentos chaves - inovaçáo $(14,5 \%)$, meio ambiente (14,5\%) e transporte (22,0\%) - que corresponderam, na época, a 51\% do total do orçamento da PC e estáo associados ao Objetivo 1 da política. Se se adiciona os investimentos dos Estados-membros oriundos de seus orçamentos, tem-se então uma explicação para o nível de desenvolvimento alcançado pelos territórios da UE.

Ao mergulhar nas subcategorias constantes da tabela 1 - não apresentada neste texto na forma completa -, percebe-se que os investimentos abarcam desde os centros de pesquisas, realizando as mais avançadas investigaçóes científicas, até uma simples creche. O orçamento apresentado a seguir contempla investimentos em infraestrutura de saúde, educaçáo, creches, habitaçáo, cultura e outros segmentos da matriz social dos Estados-membros da UE.

Em 2009, ano do relatório de Barca (2009), as demandas de bens e serviços públicos da população da comunidade estão refletidas na escolha das prioridades centrais (core priorities). Objetivos, tais como climate change, ageing, childrens e skills, são propósitos de política pública sonhados por qualquer agente público, mas que, no caso do Brasil, ainda são inalcançáveis.

O Estado brasileiro ainda não foi capaz de universalizar um conjunto de bens e serviços públicos, fundamentais para a melhoria do bem-estar social da populaçáo. Como exemplo, pode-se destacar: esgotamento sanitário; água encanada e tratada; energia elétrica no setor rural; educação primária e secundária; educação das crianças entre 2 e 6 anos; tratamento dos resíduos sólidos; transporte urbano de qualidade nas RMs; e habitação

25. Até mesmo com todos esses ganhos substanciais de bem-estar social, o número de descontentes com a PC não decresce. Barca (2009) destaca essa questão em seu relatório. As contribuições de Dijkstra, Poelman e Rodríguez-Pose (2019) e de outros pesquisadores destacam a importância do problema. 
popular. Trata-se de categorias de bens e serviços públicos que apresentam elevados deficits de oferta no nível de todas as regióes do país, especialmente nas mais atrasadas.

TABELA 2

Alocação do orçamento da Política de Coesão por categorias' (2007-2013) (Em \%)

\begin{tabular}{|c|c|}
\hline Exercício 2007-2013 & \\
\hline Total de recursos: 344.533,7 (€ milhões a preços correntes) & \\
\hline Categorias & \\
\hline Research and technological development (R\&TD) and innovation & 14,5 \\
\hline Support to firms' investment & 3,9 \\
\hline Information Society & 4,4 \\
\hline Transport & 22 \\
\hline Energy & 3,1 \\
\hline Environmental protection and risk prevention & 14,5 \\
\hline Tourism & 1,7 \\
\hline Culture & 3 \\
\hline Urban and rural regeneration & 4,2 \\
\hline Adaptability of workers and firms, enterprises and entrepreneurs & 6,6 \\
\hline Social inclusion of less-favoured persons & 2,9 \\
\hline Human capital & 7,6 \\
\hline Social infrastructure & 4,9 \\
\hline Partnership and networking & 0,4 \\
\hline Institutional capacity at national, regional and local level & 1 \\
\hline Reducing additional costs of outermost regions & 0,2 \\
\hline Technical assistance & 3,1 \\
\hline Total & 100 \\
\hline
\end{tabular}

A existência de tal deficit na oferta de bens e serviços públicos, especialmente nas áreas de saúde e educação, representa um grande obstáculo ao processo de crescimento econômico sustentado do país. ${ }^{26}$

26. A importância de bens e serviços públicos e de seus impactos no crescimento econômico está amplamente escrutinada em Capello e Nijkamp (2009). 
O objetivo da eficiência, táo desejado pelo governo federal, apresenta uma fraca resposta diante desses gargalos estruturais da economia nacional.

O fato relevante é que serviços de educação e qualificação profissional constituem o eixo 3 da PNDR (quadro 4).

A vasta literatura, de natureza teórica e empírica, dedicada aos determinantes do crescimento econômico, enfatiza a importância dos serviços educacionais no processo de desenvolvimento econômico e social de determinada sociedade. Isso se pode afirmar a respeito da importância da ampla disponibilidade de bens e serviços públicos, relacionados ao grupo da infraestrutura, ao processo de crescimento econômico e melhoria do bem-estar social dos residentes de dado território.

Após essas consideraçôes, a questão que merece uma resposta é: por que a PC foi exitosa na solução da oferta de alguns bens e serviços públicos, até mesmo com todos os percalços (crises políticas e econômicas), e as nossas experiências de política regional, desde os anos 1950 até os dias atuais, não foram capazes de preencher alguns elos faltantes da matriz social do país.

Por último, a PNDR contempla um conjunto de elementos estratégicos criados com o objetivo de orientar a operacionalização de programas e projetos que serão desenhados a partir dos eixos setoriais apresentados no quadro 3. Nesse contexto, destacam-se elementos de governança da política, de avaliação de programas e projetos, do processo de financiamento das açôes e da criação de instrumentos de informação. Algumas dessas questôes serão objeto de análise nas páginas seguintes.

\subsection{A questão da governança}

Em relatório de sua lavra, Barca (2009) dedica um espaço especial à questão da governança da PC. Enfatiza que uma boa governança é crucial no processo de implementação e operacionalização dos dez pilares da reforma apresentados na tabela 1.

Um elemento enfatizado pelo relator diz respeito à urgente necessidade de a Comissão Europeia encampar a construção do Plano de Desenvolvimento Estratégico 
Europeu $^{27}$ (European Strategic Development Framework), ao tomar como eixo de referência os dez pilares explicitados na tabela 1. Paralelamente, os Estados-membros desenhariam um documento denominado Contrato de Desenvolvimento Estratégico Nacional (National Strategic Development Contract). Esses dois documentos seriam fundamentais no processo de alocação dos recursos dos fundos em cada território.

Em relaçáo ao Brasil, existe o Plano Plurianual (PPA). Trata-se de instrumento de planejamento governamental que define as diretrizes, objetivos e metas da administração pública federal para o horizonte de quatro anos. ${ }^{28} \mathrm{O}$ PPA 2020-2023 foi aprovado pela Lei $n^{\circ} 13.971$ de 27 de dezembro de 2019. O MDR apresenta seis programas no PPA 2020-2023, constantes do Anexo I - Programas Finalísticos. A maioria dos programas apresenta uma clara convergência com a PNDR.

No caso do Brasil, a PNDR é uma política de Estado. Por via de consequência, na perspectiva do arranjo do federalismo brasileiro, o princípio da cooperação com os agentes governamentais subnacionais constitui um dos pilares para seu efetivo êxito. Em segunda perspectiva, trata-se de política do governo federal com características transversais que, para uma governança exitosa, exige diálogo permanente com as outras instâncias da administração direta do governo federal. Em terceiro lugar, há de ser levado em consideração o posicionamento da PNDR em relação a outras políticas de responsabilidade do Ministério do Desenvolvimento Regional. ${ }^{29}$

No quadro 6, elaborado a partir da análise da plataforma eletrônica do MDR, foi elencado o conjunto de políticas públicas cuja efetividade é de responsabilidade da administração do ministério. Cada política se desdobra em açôes e programas. Observa-se que o MDR é responsável pela execução de onze políticas nacionais, com abrangência territorial nacional, o que inclui a PNDR (Brasil, 2020). A primeira leitura que se pode fazer a partir das informaçóes disponibilizadas no quadro 6 , é que existe um processo

27. Barca (2009) afirma: "Particularly relevant is the introduction of the Community Strategic Guidelines and the National Strategic Reference Frameworks: whatever their actual implementation; they do represent a building block on which the proposals of this Report can be built." Em seção seguinte, o relator destaca a necessidade de "For each country of the Union, the Member State (Regions) would conclude a National Strategic Development Contract (or Contract) with the Commission, a document formally approved by the Commission committing the Member State (Regions) to a strategy and to results for the use of the funds" (op. cit., p. 166).

28. Disponivel em: <https://is.gd//kc5xim>. Acesso em: out. 2020.

29. Disponivel em: <https://bit.ly/3owz9wl>. Acesso em: set. 2020. 
de convergência entre as políticas. Açôes e programas de cada política tendem a dialogar com os Objetivos da PNDR. Por exemplo, os programas finalísticos constantes no PPA e de responsabilidade do MDR para a melhoria da infraestrutura hídrica apresenta forte aderência com os objetivos gerais da PNDR.

A fim de melhor avaliar o mecanismo de governança da PNDR frente à carteira de políticas nacionais de responsabilidade do MDR, procurou-se investigar o conteúdo regulatório de cada política. ${ }^{30}$ Utilizando-se as informaçóes disponíveis na plataforma eletrônica do ministério (Caixa Legislação - Açóes e Programas) foi possível construir o quadro 5, no qual constam as diferentes políticas, o nível de regulação e seus rebatimentos com a PNDR. Uma das preocupaçôes foi investigar qual o nível de interação dessa política com as outras - isto é, se estas "dialogavam" entre si.

QUADRO 5

Políticas administradas pelo MDR

\begin{tabular}{|c|c|}
\hline № & Especificação \\
\hline 1 & Política Nacional de Desenvolvimento Regional \\
\hline 2 & Política Nacional de Desenvolvimento Urbano \\
\hline 3 & Política Nacional de Proteção e Defesa Civil \\
\hline 4 & Política Nacional de Recursos Hídricos \\
\hline 5 & Política Nacional de Segurança Hídrica \\
\hline 6 & Política Nacional de Irrigação, observadas as competências do Ministério da Agricultura, Pecuária e Abastecimento (Mapa) \\
\hline 7 & Política Nacional de Habitação \\
\hline 8 & Política Nacional de Saneamento \\
\hline 9 & Política Nacional de Mobilidade Urbana \\
\hline 10 & Política de subsídio à habitação popular, ao saneamento e à mobilidade urbana \\
\hline 11 & Política Nacional de Ordenamento Territorial \\
\hline 12 & $\begin{array}{l}\text { Estabelecimento de diretrizes e prioridades na aplicação dos recursos dos programas de financiamento relativos ao FNO, FNE e FCO; ao FDA, } \\
\text { FDNE e FDCO; e ao Fundo Nacional de Habitação de Interesse Social (FNHIS) }\end{array}$ \\
\hline 13 & Estabelecimento de normas para o cumprimento das programações orçamentárias do Finam e do Finor \\
\hline 14 & $\begin{array}{l}\text { Estabelecimento de metas a serem alcançadas nos programas de habitação popular, saneamento básico e infraestrutura urbana realizados } \\
\text { com aplicação de recursos do Fundo de Garantia do Tempo de Serviço (FGTS) }\end{array}$ \\
\hline 15 & $\begin{array}{l}\text { Planos, programas, projetos e ações de desenvolvimento regional, metropolitano e urbano; gestão de recursos hídricos; infraestrutura e garantia da } \\
\text { sequrança hídrica; irrigacão; protecão e defesa civil e de gestão de riscos e desastres; e habitacão, saneamento, mobilidade e servicos urbanos. }\end{array}$ \\
\hline
\end{tabular}

30. Intenda-se conteúdo regulatório como a existência de um decreto do Poder Executivo que institui a referida política como é o caso da PNDR. 
As evidências indicam que, das onze políticas nacionais explicitadas como de responsabilidade do MDR e constantes na sua plataforma eletrônica, cinco não apresentam qualquer regulação, diga-se decreto de criação: desenvolvimento urbano (em construção); proteção e defesa civil; recursos hídricos; subsídio à habitação popular; e habitação. Convém lembrar ao leitor que, no quadro 3, estão explicitados os eixos de atuação da PNDR, e os eixos 4 e 5 estariam claramente associados ao potencial conteúdo regulatório das políticas nacionais referidas anteriormente, caso este existisse.

A Política Nacional de Segurança Hídrica também carece de regulação. O que existe em seu lugar é a Política Nacional de Segurança de Barragem, que não apresenta qualquer conexão com a PNDR.

A Política Nacional de Irrigação está regulamentada pela Lei no 12.787, de 11 de janeiro de 2013, que estabelece princípios, objetivos, metas etc. Existe uma observação na plataforma, chamando atenção ao leitor de que está sendo construída uma política para o setor. $\mathrm{O}$ fato relevante é que a tal lei de irrigaçáo não dialoga com a PNDR. Ao considerar a importância do tema para um dos territórios de preocupação da PNDR (semiárido do Nordeste), torna-se necessário equacionar a correspondência regulatória entre a lei

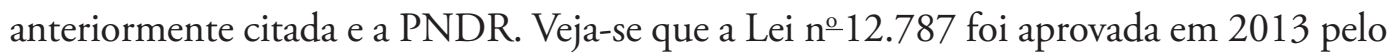
Congresso Nacional como Política Nacional, quando já vigorava a PNDR I de 2007.

Fenômeno semelhante passa-se com a Política Nacional de Saneamento. O que existe é o Marco Legal do Saneamento, aprovado recentemente no Congresso Nacional, mas que não pode ser confundido com estrutura regulatória típica de política nacional nos moldes da PNDR.

Finalmente, destaca-se a Política Nacional de Mobilidade Urbana. No contexto atual, existe a Lei no 12.587 , de 11 de janeiro 2012 que estabelece parâmetros para a operacionalizaçáo do setor. Todavia, carece da existência de um marco regulatório que possa ser identificado como a verdadeira Política Nacional de Mobilidade Urbana, nos moldes do desenho da PNDR. 
QUADRO 6

Políticas administradas pelo MDR

\begin{tabular}{|c|c|c|c|}
\hline № & Especificação & Condição de regulamentação ${ }^{1}$ & Rebatimentos com a PNDR ${ }^{2}$ \\
\hline 1 & $\begin{array}{l}\text { Política Nacional de Desenvolvimento } \\
\text { Regional }\end{array}$ & Regulação completa (2019) & Não se aplica \\
\hline 2 & Política Nacional de Desenvolvimento Urbano & $\begin{array}{l}\text { Sem regulação. Não está disponível na } \\
\text { plataforma. }\end{array}$ & Nenhum rebatimento \\
\hline 3 & Política Nacional de Proteção e Defesa Civil & Sem regulação & Nenhum rebatimento \\
\hline 4 & Política Nacional de Recursos Hídricos & Sem regulação & Nenhum rebatimento \\
\hline 5 & Política Nacional de Segurança Hídrica & $\begin{array}{l}\text { Sem regulação. Existe a Política Nacional de } \\
\text { Segurança de Barragem }\end{array}$ & Nenhum rebatimento \\
\hline 6 & $\begin{array}{l}\text { Política Nacional de Irrigação, observadas as } \\
\text { competências do Mapa }\end{array}$ & $\begin{array}{l}\text { Lei no.12.787, de } 11 \text { de janeiro de } 2013 . \text { Será } \\
\text { elaborada uma nova política }\end{array}$ & Nenhum rebatimento \\
\hline 7 & Política Nacional de Habitação & Sem regulamentação & Nenhum rebatimento \\
\hline 8 & Política Nacional de Saneamento & $\begin{array}{l}\text { Sem regulamentação. Neste momento, existe } \\
\text { o Marco Legal do Saneamento }\end{array}$ & Nenhum rebatimento \\
\hline 9 & Política Nacional de Mobilidade Urbana & $\begin{array}{l}\text { Lei no } 12.587 \text {, de } 3 \text { janeiro de } 2012 \text {. Sem } \\
\text { regulamentação }\end{array}$ & Nenhum rebatimento \\
\hline 10 & $\begin{array}{l}\text { Política de subsídio à habitação popular, ao } \\
\text { saneamento e à mobilidade urbana }\end{array}$ & Sem regulamentação & Nenhum rebatimento \\
\hline 11 & Política Nacional de Ordenamento Territorial & Sem regulamentação & Nenhum rebatimento \\
\hline
\end{tabular}

Fonte: Plataforma eletrônica do MDR. Agosto de 2020.

Elaboração do autor.

Notas: ' Procurou-se investigar o nível de regulamentação de cada política, ao comparar-se com a PNDR de 2019.

${ }^{2} \mathrm{~A}$ partir da leitura das leis - quando existiam -, procurou-se investigar a aderência à PNDR.

Em síntese, a PNDR está parcialmente insulada no contexto do organograma organizacional do MDR. Setores extremamente importantes - por exemplo, habitação e saneamento e irrigação - carecem de regulaçôes que, caso existissem, auxiliariam sobremaneira a efetividade da PNDR. Trata-se de atividades fundamentais para alcançar os objetivos de eficiência e equidade, elementos centrais da PNDR. 


\subsection{Do processo de avaliação e monitoramento da PNDR}

Recorrendo mais uma vez às contribuiçóes do relatório de Barca (2009), o relator clama pela necessidade de um sistema de avaliação da PC, segundo a nova abordagem (place-based approach), que seja capaz de responder a duas questôes: ${ }^{31}$ o que funciona (what works?), onde a intervençáo está produzindo efeito e para quem - isto é, quem se apropria da intervenção (for whom?).

$\mathrm{Na}$ sequência, o relator destaca que a avaliação de impactos constitui uma ferramenta central para o sucesso da PC e, na oportunidade, sugere algumas orientaçóes para alcançar os objetivos, como: ${ }^{32}$

- separar rigorosamente o uso de indicadores, em que destaca que os indicadores de resultados diferem de indicadores de avaliação de impactos;

- prestar atenção especial nos métodos contrafactuais, em que seja possível comparar o grupo beneficiário com um grupo de controle;

- tentar realizar avaliação de impacto prospectivamente - isto é, antes da implantação da intervenção;

- realizar experimentos aleatórios;

- reforçar o papel da Comissão Europeia por meio da criaçáo de clearing house e de think tank; e

- ampliar a disponibilidade de dados - ou seja, coletar dados e informaçóes capazes de auxiliar no processo de avaliação de impactos.

O Brasil no contexto de avaliação e mensuração dos impactos da PNDR parece estar bem situado. O capítulo II da lei da PNDR que trata da governança destaca a criação da Câmara de Política de Integração Regional e, entre suas competências, está a

31. "Cohesion policy has invested significantly in the learning process: in creating networks, facilitating exchange of experience, and promoting evaluation. As chapter II showed, the policy has produced relevant results, but improvements are much-needed in two directions: the capacity to apply lessons must be strengthened; and the failure to develop knowledge on "what works", i.e. on whether interventions are producing effects, and "for whom" must be remedied" (Barca, 2009, p.178, grifo nosso).

32. Os elementos são: "1. Rigorous separation from the use of indicators, 2. A focus on counterfactual methods 3. Prospective impact evaluation; 4. Experimenting randomisation; 5 . Commission role: clearing house and think tank; 6 . Data availability" (Barca, 2009, p. 179). 
criação de instrumentos de avaliação e monitoramento explicitados nos parágrafos VI, VIII e XIV da PNDR.

O atual Ministério do Desenvolvimento Regional criou, ainda na condição de Ministério da Integração Nacional, uma parceria muito profícua com a Diretoria de Estudos e Políticas Regionais, Urbanas e Ambientais (Dirur) do Ipea, ${ }^{33}$ por meio dos Acordos de Cooperaçáo nos 19/2013 e 31/2013, para realizar estudos de avaliaçáo de impactos das açóes da PNDR. Na condição de principal centro de inteligência do governo federal, o Ipea tornou-se o think tank parceiro do MDR e os resultados têm sido promissores.

Nesse contexto, percebe-se que a governança da PNDR não difere das boas práticas internacionais em relação à avaliação de políticas.

\subsubsection{0 impacto dos fundos constitucionais e a PNDR: avaliação quantitativa e qualitativa}

Como anteriormente destacado, a PNDR dispóe de instrumentos de financiamento destinados ao desenvolvimento dos territórios economicamente atrasados. Esses instrumentos foram criados pela CF/1988 e regulamentados por intermédio da Lei no 7.827/1989. Trata-se dos fundos constitucionais para as regióes Nordeste, Amazônia e Centro-Oeste, as mais atrasadas do país em ritmo de desenvolvimento. Resende, Silva e Silva Filho $(2017)^{34}$ destacam que as fontes desses fundos são "provenientes, fundamentalmente, de 3\% da arrecadaçáo do Imposto sobre Renda e Proventos de Qualquer Natureza (Imposto de Renda - IR) e do Imposto sobre Produtos Industrializados (IPI), bem como de retornos e resultados de suas aplicaçóes." Os autores acrescentam como fonte adicional de recursos

o Fundo de Investimento da Amazônia (Finam) e o Fundo de Investimento do Nordeste (Finor), cujos recursos se originam da aplicação de parte dos impostos de renda das empresas e são destinados aos empreendimentos relevantes do desenvolvimento regional (Resende, Silva e Silva Filho, 2017, p. 10).

33. Resende (2017). A publicação é da mais alta relevância e sua leitura é referência no assunto. Apresenta um conjunto de artigos de vários pesquisadores do Ipea direcionados para a avaliação da PNDR, utilizando diferentes metodologias. 34. Resende, Silva e Silva Filho (2017). Leia-se a Introdução do livro elaborada pelo editor. 
Os fundos constitucionais aludidos anteriormente têm recebido atenção especial dos gestores da PNDR. Os impactos sobre a dinâmica econômica das regiôes têm sido objeto de avaliação. A razão de tal atenção está intrinsicamente associada aos objetivos do crescimento econômico (eficiência) estabelecidos como um dos pilares da PNDR.

O trabalho de Resende, Silva e Silva Filho (2017) procura avaliar o impacto dos três fundos constitucionais sobre o crescimento do PIB per capita nas regióes Nordeste, Norte e Centro-Oeste.

No capítulo de revisão da literatura, exaustivo para os padróes acadêmicos, os autores defrontam-se com um fenômeno digno de menção. $\mathrm{Na}$ oportunidade, eles afirmam que

a maioria dos trabalhos acredita que a utilização dos fundos está se concentrando nos municípios mais desenvolvidos. A consequência desta evidência é preocupante, na medida em que estes fundos não estariam alcançando seus objetivos, como a política regional de redução das desigualdades intrarregionais (Resende, Silva e Silva Filho, 2017).

$\mathrm{Na}$ sequência, os autores apresentam o modelo de análise e discutem as ferramentas econométricas utilizadas, com destaque para a econometria espacial. Empregam a técnica de painel associando corte transversal com séries temporais. A técnica é fundamental para captar os efeitos de transbordamento dos investimentos no território.

No que concerne ao Fundo Constitucional de Financiamento do Nordeste, constatou-se que os resultados das estimaçóes do modelo se mostraram extremamente robustos para os municípios enquadrados na categoria dinâmicos e de baixa renda. Nesse teste, os resultados "reforçam a evidência do papel exercido pelo FNE sobre a redução das desigualdades nos níveis macrorregional e intrarregional." No teste relativo à dependência espacial, foi observado que, para as tipologias definidas como dinâmicas, foi notada uma relaçáo positiva entre o FNE do grupo com o crescimento do PIB per capita dos municípios vizinhos. Os autores concluem que essa dinâmica é extremamente auspiciosa, pois demonstra que o crescimento de determinado município contribui para o crescimento de seu vizinho, e tal comportamento é fundamental para disseminar o crescimento do território.

No tocante ao FNO, os resultados mostraram que os recursos do fundo foram bastante fortes para a tipologia dinâmica e, com menor força, para a tipologia alta renda, 
sobre o crescimento do PIB per capita em nível municipal. As estimativas indicam redução da desigualdade entre as macrorregiôes da região Norte, mas isso não se pode afirmar a respeito das desigualdades no contexto intrarregional. A justificativa para tal fenômeno está associada à existência de número reduzido de regióes de alta renda na regiáo.

Um fenômeno digno de menção diz respeito à ausência de impacto dos empréstimos do FNO na escala microrregional. No que concerne ao teste da dependência espacial, os autores afirmam que "apenas as variáveis de controle exerceram papel estatisticamente significante sobre o crescimento do PIB per capita da vizinhança”" (Resende, Silva e Silva Filho, 2017). Os autores acreditam que existe uma fraca interação entre as localidades da regiáo, pelo menos no que se refere à relação entre o FNO e o crescimento econômico.

Finalmente, destacam-se os resultados do impacto do FCO no crescimento da economia do Centro-Oeste. Os recursos do fundo foram positivos para o crescimento do PIB per capita em relação aos municípios de alta renda. Como $46 \%$ dos municípios da região Centro-Oeste estão enquadrados no grupo de alta renda, então é possível afirmar que o desempenho do FCO contribuiu para a redução das desigualdades na regiáo. Isso não se pode afirmar sobre a redução das desigualdades intrarregionais, posto que os municípios de alta renda foram os mais beneficiados com os recursos do FCO.

O processo de avaliação dos impactos da PNDR realizado pela equipe do Ipea foi inovador no uso de técnicas e ferramentas. Além do uso de modelos de crescimento econômico combinado com ferramentas estatísticas sofisticadas, os técnicos também inovaram ao empregar o modelo de pesquisa qualitativa, para avaliar a qualidade das intervenções associadas aos objetivos da PNDR.

A pesquisa qualitativa (Monteiro Neto et al., 2017) desenvolvida pela equipe do Ipea representa uma das melhores contribuições da instituição para a avaliação da PNDR. Trata-se, também, de grande avanço metodológico no processo de avaliação da política de desenvolvimento regional. Foram escolhidos dezoito municípios das regióes Norte, Nordeste e Centro-Oeste para realizaçáo das entrevistas. Foram consultados os gerentes das agências bancárias ofertantes do crédito, bem como as empresas e os empreendedores demandantes do crédito. As entrevistas foram realizadas entre setembro de 2014 e junho de 2015. O foco da pesquisa estava centrado na análise do impacto dos instrumentos financeiros que a PNDR busca coordenar e articular. 
A pesquisa, além de captar as percepções dos demandantes e ofertantes de recursos dos fundos constitucionais, foi além ao investigar a percepção de atores locais "(secretários municipais de planejamento ou fazenda, gestores de organizaçóes não governamentais, reitores ou pró-reitores universitários etc.)" (Monteiro Neto et al., 2017) em relação à PNDR.

Os principais resultados da pesquisa qualitativa realizada com os empresários estáo apresentados no quadro 7. Destaca-se, em primeiro lugar, a importância do sistema financeiro público, por meio de seus bancos de fomento, para a operacionalização da PNDR. Até mesmo se reconhecendo a "burocracia infernal" (palavras de um entrevistado) operante nas instituiçôes bancárias do governo para tomar um empréstimo para capital de giro ou para expansão dos negócios, fica patente para qualquer analista que a potencial trajetória exitosa da política depende dessas instituiçôes. À luz das respostas dos empresários, o sistema financeiro privado não é um bom parceiro e, certamente, desconhece a importância da PNDR para as regiōes atrasadas do país. Parodiando César, existem, todavia, outros vilóes da política que estão do outro lado do Rubicáo.

Ainda segundo os entrevistados, os efeitos positivos dos recursos dos fundos são reduzidos quando se leva em conta a carga tributária elevada e os gargalos de infraestrutura econômica com que se depara o setor produtivo. Se, por um lado, a PNDR intenta com uma mão promover o crescimento com eficiência e inclusão social - especialmente dos territórios mais atrasados do país -, seu mentor, o governo federal, por outro lado, com a outra mão, cria um conjunto de taxas, impostos e contribuiçôes que praticamente inviabiliza a atividade produtiva de micros, pequenos e médios empresários. $\mathrm{O}$ crescimento econômico fica prejudicado. Afora a questão dos impostos, esse mesmo governo não colabora com o setor produtivo em um item fundamental para o sucesso de qualquer empreendimento privado: a disponibilidade de infraestrutura de qualidade. No caso dos empresários pesquisados, o destaque fica para a deficiência de estradas. A restriçáo no segmento dos transportes tem dois efeitos perversos: encarece o custo do produto final para o empresário local, forçando-o a diminuir o preço ao consumidor a fim de sobreviver ante a concorrência extrarregional. Isso afeta sua margem de lucro e, por via de consequência, sua capacidade de acumulaçáo. O segundo efeito encontra-se nas compras dos insumos e matérias-primas produzidas fora da regiáo. Como decorrência da precariedade das estradas, os fornecedores embutem um custo adicional no frete das mercadorias, o que gera um preço unitário final mais alto de equipamentos, insumos e 
matérias-primas. Nesses tempos de modernidade, a questão da comunicação eletrônica (internet e sinal de celular) representa outro constrangimento para os empresários, com rebatimentos negativos na produtividade e lucratividade dos negócios.

Outra questão captada na pesquisa diz respeito à escassez de mão de obra qualificada. Trata-se da ausência de escolas técnicas, de institutos tecnológicos e de universidades públicas, fundamentais na formação de força de trabalho para suprir as necessidades dos empresários regionais. Esse é um serviço de natureza pública da mais alta relevância e que náo pode contar com o apoio do setor privado.

Por último, destaca-se a percepção dos empresários sobre o futuro dos negócios. As impressôes captadas pelos pesquisadores são dignas de citação:

Os entrevistados foram quase unânimes em apontar que as dificuldades por eles enfrentadas acerca de altos impostos, carência de mão de obra e deficiência na infraestrutura não terão solução em horizonte próximo. Seus comentários são pessimistas acerca da atuação governamental (nos três níveis de governo) para criar soluçôes realistas para os problemas existentes. Entretanto, é preciso ressaltar que o estudo apontou que a grande maioria dos entrevistados não mencionou ter procurado, diretamente ou por meio de associaçóes patronais, levar suas atribulaçóes ao nível de governo competente.

A segunda parte da pesquisa procura captar a percepção dos gerentes das agências bancárias dos bancos de fomento público que atuam nas três regiôes, supridores de recursos financeiros aos empresários dos municípios pesquisados.

Uma pergunta fundamental feita pela equipe estava relacionada à política de financiamento da atividade produtiva e sua aderência à PNDR. As evidências indicam que o Basa e o BNB estão articulados com as diretrizes do MDR e, consequentemente, à PNDR. Os planos operacionais anuais das duas instituiçôes de fomento regional incorporam as diretrizes da PNDR no que concerne aos objetivos e às estratégias. No caso específico das regiốes menos dinâmicas, o Basa opera com o FNO itinerante e o $\mathrm{BNB}$, com os programas Microcrédito e Crediamigo. Essa estratégia funciona para as regiốes Norte e Nordeste. Em relação à região Centro-Oeste, cujo agente financeiro é o Banco do Brasil (BB), as evidências não são positivas. Em primeiro lugar, alguns gerentes de agências desconhecem a existência da PNDR. Todavia, o mais grave é que o plano operacional do banco, desenhado no nível de diretoria, apresenta reduzida aderência à 
PNDR. Como bem destacam os analistas do Ipea, os recursos do FCO confundem-se com as demais linhas de crédito operacionalizadas pela ampla e diversificada carteira do banco.

QUADRO 7

PNDR: pesquisa qualitativa - percepção dos tomadores de recursos - empresários (2014-2015)

\begin{tabular}{|c|c|c|c|}
\hline № & Perguntas - especificação & Respostas & Observação \\
\hline \multirow{5}{*}{1} & \multirow{5}{*}{$\begin{array}{l}\text { Motivação para a tomada de } \\
\text { recursos }\end{array}$} & Custo e carência & $\begin{array}{l}\text { Banco Nacional de Desenvolvimento Econômico e } \\
\text { Social (BNDES) como segunda opção }\end{array}$ \\
\hline & & Fonte de recursos sem substituto à altura & - \\
\hline & & Burocracia como custo & Ponto negativo \\
\hline & & Mercado local como foco de atuação & - \\
\hline & & Investimento novo para expansão da produção & $\begin{array}{l}\text { Capital de giro e compra de equipamentos/investi- } \\
\text { mento em novas instalações }\end{array}$ \\
\hline \multirow{3}{*}{2} & \multirow{3}{*}{$\begin{array}{l}\text { Perfil da empresa represen- } \\
\text { tativa }\end{array}$} & $\begin{array}{l}\text { Pequeno porte } \\
\text { Mercado regional }\end{array}$ & - \\
\hline & & Capta recursos do FCFs por poucas vezes & - \\
\hline & & Empréstimos mais para ampliação da planta & - \\
\hline \multirow{2}{*}{3} & \multirow{2}{*}{$\begin{array}{l}\text { Decisão locacional: escolha } \\
\text { do local }\end{array}$} & Onde se vive, trabalha-se & Relacionada com a trajetória familiar do empresário \\
\hline & & Onde se vive, inventam-se negócios & - \\
\hline \multirow{4}{*}{4} & \multirow{4}{*}{$\begin{array}{l}\text { Entraves ao desenvolvimento } \\
\text { dos negócios }\end{array}$} & Impostos (elevada carga tributária) & - \\
\hline & & Infraestrutura: qualidade das estradas & - \\
\hline & & Carência de mão de obra de boa qualidade & - \\
\hline & & Comunicação eletrônica precária & Internet e telefonia móvel \\
\hline \multirow{2}{*}{5.} & \multirow{2}{*}{ Percepção do futuro } & Sem mudanças à vista. Sem solução no médio prazo & - \\
\hline & & Pouca interação com os governantes & - \\
\hline \multirow{2}{*}{6} & \multirow{2}{*}{$\begin{array}{l}\text { Mercado e } \\
\text { fornecedores }\end{array}$} & Mercado local e municípios no entorno & \\
\hline & & De fora da região. São Paulo com maior força & \\
\hline
\end{tabular}

Fonte: Monteiro Neto et al. (2017).

Elaboração do autor.

A percepção dos gerentes das agências dos três bancos de fomento, em relação ao papel dos governos (federal, estadual e municipal) como emulador e facilitador do processo de crescimento e desenvolvimento dos territórios pesquisados coincide, em grande medida, com a visão dos empresários. Escassez de mão de obra qualificada para suprir as necessidades dos empresários, elevada carga tributária que afeta a rentabilidade dos negócios e infraestrutura precária - especialmente no que concerne às estradas - são fatores que prejudicam o maior desenvolvimento dos negócios nos municípios pesquisados. 
QUADRO 8

PNDR: pesquisa qualitativa - Percepção dos fornecedores de crédito - gerentes de bancos (2014-2015)

\begin{tabular}{|c|c|c|}
\hline Perguntas & Respostas & Observação \\
\hline \multicolumn{3}{|c|}{ Características do financiamento } \\
\hline \multirow{2}{*}{ Norte } & Para capital de giro e implantação & \\
\hline & Micro e pequenas empresas & \\
\hline \multirow{2}{*}{ Nordeste } & Operação de implantação e giro & \\
\hline & Lógica: implantação/modernização/giro & \\
\hline \multirow{2}{*}{ Centro-Oeste } & Micro e pequenos empresários & \\
\hline & Expansão e modernização-giro é residual & Setores serviços \\
\hline \multicolumn{3}{|c|}{ Financiamento do desenvolvimento regional: aderência dos FCFs à PNDR } \\
\hline Norte & Existe aderência. Por meio do plano de aplicação do banco & \\
\hline Nordeste & Existe aderência. Plano operacional anual vincula-se à PNDR & Uso do Microcrédito e Crediamigo \\
\hline Centro-Oeste & Gerentes desconhecem a PNDR. 0 banco tem suas diretrizes próprias & \\
\hline \multicolumn{3}{|c|}{ Processo de concessão de crédito } \\
\hline Norte & Municípios menos dinâmicos, recursos realizados e FNO itinerante & $\begin{array}{l}\text { Colaboração dos órgãos de assistência } \\
\text { técnica }\end{array}$ \\
\hline Nordeste & Municípios menos dinâmicos conduzidos por agentes do desenvolvimento & \\
\hline Centro-Oeste & Banco divulga seus portfólios de negócios com os empresários. & $\begin{array}{l}\text { Gerentes não conhecem a PNDR. Não } \\
\text { existe orientação explicita a favor da } \\
\text { PNDR }\end{array}$ \\
\hline \multicolumn{3}{|c|}{ Fatores que influenciam a inadimplência } \\
\hline \multirow{2}{*}{ Norte } & Ausência e insuficiência de gestão do empreendimento & \\
\hline & Fatores de mercado e localização & \\
\hline \multirow{2}{*}{ Nordeste } & Qualidade da mão de obra & \\
\hline & Problemas de experiência do empreendedor & \\
\hline Centro-Oeste & Gestão dos negócios & \\
\hline \multicolumn{3}{|l|}{ Papel dos governos } \\
\hline \multirow{2}{*}{ Norte } & Dificuldades de transporte-infraestrutura & \\
\hline & Acesso aos mercados do produtor e consumidor & \\
\hline \multirow{2}{*}{ Nordeste } & Baixa qualificação da mão de obra & \\
\hline & Pesada carga tributária & \\
\hline \multirow{2}{*}{ Centro-Oeste } & Baixa qualificação da mão de obra & \\
\hline & Elevada carga tributária & \\
\hline
\end{tabular}

Fonte: Monteiro Neto et al. (2017).

Elaboração do autor. 
O resultado da pesquisa qualitativa realizada pela equipe do Ipea pode dar uma grande contribuição às futuras análises de impacto. Em primeiro lugar, identificou-se um conjunto de variáveis que, a partir de agora, podem ser operacionalizadas por meio de modelos econométricos e quantificadas por intermédio de elasticidades e/ou multiplicadores. Em segundo lugar, abriu uma nova fronteira metodológica para a avaliação de outras programas do MDR de base local. Em terceiro, provocou maior interação dos técnicos/analistas com os demandantes das políticas públicas, oportunizando aos técnicos o conhecimento da realidade social, econômica e ambiental do território onde operam as políticas.

\subsection{Da montagem de um sistema de informação e monitoramento}

Recorrendo mais uma vez ao relatório de Barca (2009), o autor destaca que uma das fraquezas da governança da PC gravita em torno de uma imperfeita base de dados. Primeiro, torna-se necessário então construir uma base de informaçôes que incorpore um conjunto de variáveis de natureza demográfica, geográfica, econômica e social, com características universais - isto é, que esteja disponível para todas as unidades territoriais (desenvolvidas e atrasadas). Segundo que o princípio de homogeneidade do indicador seja um elemento-chave na construção da base, a fim de que os resultados das pesquisas de avaliação de impacto sejam os mais fidedignos possíveis. Na literatura empírica, que versa sobre os estudos de avaliação da política regional na União Europeia, existe sempre um destaque, notadamente negativo, para a existência de um quadro de assimetria de informação quantitativa e até mesmo qualitativa entre as Nuts (regiōes administrativas) da UE. As consequências de tal assimetria refletem-se na qualidade dos resultados das investigaçóes.

Sem embargo, o Brasil não se defronta com esse problema. O país dispóe de uma instituição, o IBGE, que funciona como o grande gerador e provedor de informaçóes econômicas e sociais para todas as categorias de demandantes (público e privado), cobrindo todos os recantos do território nacional.

O Ministério do Desenvolvimento Regional - ao operar de forma cooperativa com o IBGE, este na condição de provedor de uma cesta de dados - criou uma ferramenta poderosa para monitorar a aplicação das políticas de desenvolvimento regional. Trata-se do Observatório Nacional do Desenvolvimento Regional (ODR). Segundo o site do MDR, 
o ODR - construído sob a plataforma ArcGIS - é uma ferramenta web de apresentação de malhas, dados e indicadores georreferenciados. Também possui recursos para criação de mapas temáticos e de calor, ediçôes personalizadas, além de permitir a elaboração de gráficos e tabelas com cruzamento de informações, para comparação sobre a evolução de índices brasileiros de desenvolvimento.

Em se tratando de ferramentas de monitoração e avaliaçáo, pode-se afirmar que o Brasil está muito bem posicionado no conceito da comunidade internacional. A PNDR dispóe de ferramenta que pode contribuir positivamente para o incremento dos índices de eficiência e eficácia dos programas e das políticas públicas gerenciadas pelo MDR.

\subsection{Rotas da integração nacional: uma experiência na escala meso e microrregional}

Por volta de 2014, o governo federal, por meio do extinto MI, hoje MDR, criou o programa denominado rotas de integração nacional. A proposta era formar redes de arranjos produtivos locais (APLs) associados a cadeias produtivas estratégicas capazes de promover a inclusão produtiva e o desenvolvimento sustentável das regiôes brasileiras priorizadas pela PNDR (Coelho, 2017).

O programa tem uma história. Em primeiro lugar, o MI contratou, por meio de convênio, a Rede de Pesquisa em Sistema Produtivo e Inovativos Locais da Universidade Federal do Rio de Janeiro (Redesist/UFRJ), que, por meio de seus pesquisadores, indicou as cadeias produtivas estratégicas que definiriam as rotas de integraçáo. Esse estudo abrangeu o contexto socioprodutivo e ambiental de cada região do país. As cadeias produtivas definidas pela Redesist estáo apresentadas no quadro 9.

QUADRO 9

APLs, segundo as macrorregiões: Redesit (2015)

\begin{tabular}{|l|l|l|l|l|}
\hline Norte & \multicolumn{1}{|c|}{ Nordeste } & \multicolumn{1}{|c|}{ Centro-Oeste } & \multicolumn{1}{|c|}{ Sudeste } & \multicolumn{1}{c|}{ Sul } \\
\hline Açaí e frutos da Amazônia & Mel e produtos das abelhas & Leite & Fruticultura & Leite e laticínios \\
\hline Piscicultura e aquicultura & Ovinocaprinocultura & Piscicultura & Cultura e turismo & Confecções \\
\hline Biodiversidade da floresta & Cultura e turismo & Madeira e móveis & Moda & Tecnologia da informação (TIs) \\
\hline
\end{tabular}

Fonte: Coelho (2008, p. 20).

Do leque de APLs definidos pela Redesit, o então MI escolheu seis para iniciar a execução do programa. Segundo informaçôes disponíveis na plataforma eletrônica do 
MDR (2020), as rotas em execução são as seguintes: i) açaí; ii) biodiversidade; iii) cacau; iv) cordeiro; v) leite; e vi) mel.

A implantação do programa exigiu um amplo esforço de governança do MDR. O sucesso do programa dependia, em primeiro lugar, de um trabalho de articulação dos entes sub-regionais (estados e municípios); em segundo, das instituiçóes de fomento, como bancos regionais; em terceiro, das ONGs operando nos territórios do programa - também dos órgãos de pesquisa como a Embrapa; e, por último, da sensibilizaçáo da clientela (produtores) operando no APL. A construçáo do programa demandou muitos encontros, reunióes e oficinas com os agentes envolvidos. Coelho (2017, p. 18) destaca que:

as Rotas apresentam, simultaneamente, uma dimensão territorial e setorial em sua concepção. $\mathrm{O}$ recorte territorial define o espaço a ser trabalhado, de acordo com a tipologia territorial da PNDR (figura 2), enquanto o recorte setorial obedece aos critérios descritos no quadro 1 (Brasil, 2014).

Trata-se de programa federal que atende aos principais objetivos da PNDR (eficiência e equidade) de forma simultânea. Isso representa grande diferencial na política de desenvolvimento regional, especialmente em se tratando do perfil da clientela, muitas vezes singelas unidades produtoras operadas por indivíduos com grande sensibilidade empreendedora, mas desprovidos de qualquer erudição em assuntos relacionados a gestão de negócios.

A pesquisa qualitativa, desenvolvida pelo Ipea - comentada anteriormente -, centrada na avaliaçấo dos fundos constitucionais, destaca essa questão. Os gerentes dos bancos estatais de fomento indicaram que a reduzida capacidade de gestáo dos micros e pequenos empresários representava um grande obstáculo ao desenvolvimento dos negócios.

O programa Rotas da Integração Nacional, como foi desenhado, pode tornar-se um ponto de inflexáo na trajetória da PNDR. Trata-se de programa que promove a articulação dos agentes públicos em todos os níveis, bem como dos privados (bancos de fomento, fornecedores de insumos e de serviços), com o objetivo de aprofundar a inclusáo econômica e social de um grupo de empreendedores, evitando que eles caiam na armadilha da ineficiência econômica e da exclusão social. 
A criação de um desenho de avaliação de impactos na dimensão prospectiva e uma avaliação de acompanhamento dos APLs podem ser de grande importância para o sucesso do empreendimento.

Barca (2009) dedica uma atenção especial à questão da avaliação desse tipo de ação territorial. Em sua opinião, trata-se de estratégia válida para vencer as armadilhas da eficiência e da inclusão social.

\section{CONCLUSÕES E RECOMENDAÇÕES}

A partir das evidências destacadas neste estudo sobre a operacionalização da Política de Coesão e da PNDR, em consonância com os destaques apresentados pelo relatório de Barca (2009), é possível afirmar, em primeiro lugar, que os resultados alcançados pela PC, em se tratando de desenvolvimento regional, foram importantes. Os europeus da União conseguiram ampliar, de forma significativa, a oferta de bens e serviços de infraestrutura, o que gerou crescimento com inclusão. Essa construção exitosa (quase cinquenta anos) se processou em um cenário heterogêneo: tempos de bonança econômica e estabilidade política com períodos de crise econômica sistêmica, de caráter endógeno e exógeno, associados a fortes ruídos de natureza geopolítica. No seu relatório, Barca (2009) destaca que esse resultado foi alcançado graças à forte participação dos investimentos governamentais. $\mathrm{O}$ mercado, solitariamente, não teria capacidade para solucionar essa restrição estrutural.

O Brasil, por meio da ação do governo federal, tem desenhado desde a metade dos anos 1950 - quase a mesma temporalidade da Política de Coesão europeia - políticas de desenvolvimento regional, sempre buscando solucionar a herança negativa de nossa formação como naçáo; qual seja, a desigualdade de produto bruto per capita no território, bem como a distribuição de renda e riqueza das famílias brasileiras, em que $1 \%$ das famílias detém, nos dias atuais, mais de $20 \%$ da riqueza nacional. Assim, as desigualdades regionais, associadas à perversa distribuição pessoal da riqueza nacional, são fatores que "minam" os fundamentos da construção de uma verdadeira nação.

A PNDR é mais uma tentativa, mais um esforço, do governo federal, no sentido de diminuir, por intermédio da construção de políticas públicas focadas no território, 
as desigualdades de produto e renda entre os residentes. Os objetivos da política são meritórios. Mas, com base nas evidências apresentadas em seçôes precedentes, esta já nasceu com deformaçóes que não foram equacionadas no tempo. Com certeza, a mais importante foi a não criação do FNDR.

A criação e a operação desse instrumento de financiamento, cujos recursos seriam não reembolsáveis, tornaria a PNDR uma política de Estado de grande impacto. Comparando-se a trajetória e a experiência das duas políticas de desenvolvimento regional (PC versus $\mathrm{PNDR}$ ), é possível admitir que uma das respostas para nosso atraso estrutural na oferta dos ditos bens públicos básicos reside na ausência dos fundos estruturais e setoriais. O desenho dos fundos ensejou um fluxo permanente de recursos para investimento aos Estados-membros e regiôes da Europa, embora sujeito a condicionalidades, capaz de universalizar os bens e os serviços públicos mais comezinhos de uma sociedade.

A PNDR é parte da estrutura regimental do MDR. Esse ministério opera apoiado no Planejamento Estratégico Institucional (PEI) do período 2019-2023, construído com o apoio da Escola Nacional de Administração Pública (Enap). O PEI está articulado ao PPA do governo federal. O MDR, segundo o Decreto $n^{\circ} 10.290$, de 24 de março de 2020, tem sob sua responsabilidade o gerenciamento de onze políticas nacionais de desenvolvimento. Algumas políticas não dialogam com a PNDR. Neste momento, é o PEI que está contribuindo para a solução desse paradoxo.

A problemática da análise dos impactos das açóes da PNDR, comentada em seçáo anterior, representa outro elemento que pode corroer os ganhos de eficácia da PNDR. Os impactos dos FCFs foram estudados para as regiōes Norte, Nordeste e Centro-Oeste em duas perspectivas: análises quantitativa e qualitativa. A quantitativa apresentou resultados promissores relativo aos efeitos dos FCFs no crescimento econômico das regióes pesquisadas. A qualitativa, por sua vez, identificou um fenômeno que Barca (2009) definiu como as "armadilhas da eficiência e inclusão social" que devem ser evitadas. Os empresários, tomadores dos empréstimos, reclamam das péssimas condiçôes da infraestrutura das estradas, dos sistemas de comunicação eletrônica (telefonia móvel e internet), da escassez de máo de obra qualificada e da elevada carga tributária, como fatores negativos ao processo de acumulação e crescimento econômico. Os gerentes das agências dos bancos que administram os fundos apresentaram um cenário não muito lisonjeiro para o futuro dos negócios, em razão da alta carga tributária, da escassez de infraestrutura e do 
baixo nível de erudição dos empresários em assuntos relacionados à gestão de negócios. O inquérito constatou que a PNDR é referência na definição das políticas de ação dos bancos operando os FCFs no Norte e no Nordeste. Todavia, os gerentes de agências do banco que administra o FCO não possuíam conhecimento da PNDR.

O programa Rotas da Integração Nacional apresenta um desenho operacional bastante coerente com os objetivos da PNDR. O programa pode se tornar um ponto de inflexão na trajetória da política, pois pretende articular - por meio de um processo participativo e cooperativo - os diferentes atores de cadeias produtivas de elevado potencial de crescimento.

Por fim, o ODR é uma excelente ferramenta desenvolvida pela equipe do MDR. Trata-se de base de dados que, se bem gerenciada, pode gerar substanciais ganhos de efetividade à PNDR. O Brasil está muito bem posicionado nessa questáo.

\section{REFERÊNCIAS}

BACELAR, T. Por uma política nacional de desenvolvimento regional. Revista Econômica do Nordeste, v. 30, n. 2, abr./jun. 1999.

BALDISSERA, F. A história da integração europeia: do pós guerra a Maastricht - tratados e instituições. 2012. Trabalho de Conclusão de Curso (Graduação) - Pontifícia Universidade Católica do Rio Grande do Sul, Porto Alegre, 2012. Disponível em: <https://bit.ly/3oq9SnH>.

BALEIRAS, R. N. Que mudanças na Política de Coesão para o horizonte 2020? In: VIEGAS, J. M.; DENTINHO, T. P. (Coord.). Desafios emergentes para o desenvolvimento regional. Cascais: Princípia, 2010. p. 349-375.

BARCA, F. An agenda for a reformed cohesion policy: a place-based approach to meeting European Union challenges and expectations. [s.1.]: Apr. 2009. Disponível em: <https:// is.gd/9EMagi>.

BARONE, G.; DAVID, F.; BLASIO, G. Boulevard regional of broken dreams: the ends of the EU funding (1997: Abruzzi, Italy). Science and Urban Economics, v. 60, p. 31-38, Sept. 2016.

BECKER, S. O.; EGGER, P. H.; EHRLICH, M. von. Effects of EU regional policy: 19892013. Regional Science and Urban Economics, v. 69, p. 143-152, Mar. 2018.

BRASIL. Presidência da República. Secretaria de Comunicação Social. Programa Brasil em Açáo - dois anos. Brasília: PR, 1998.

74 
Presidência da República. Secretaria-Geral. Decreto no 9.810, de 30 de maio de 2019. Institui a Política Nacional de Desenvolvimento Regional. Diário Oficial, Brasília, p. 6, 30 maio 2019.

Decreto no 10.290 , de 24 de março de 2020. Aprova a estrutura regimental e o quadro demonstrativo dos cargos em comissão e das funçóes de confiança do Ministério do Desenvolvimento Regional e remaneja e transforma cargos em comissão e funçôes de confiança. Diário Oficial da Uniáo, edição 57-B, p. 1, 24 mar. 2020. Seção 1 - extra.

CANO, W. 10 Anos da Política Nacional de Desenvolvimento Regional - PNDR: avanços e entraves. In: ENCONTRO NACIONAL DA ASSOCIAÇÃO NACIONAL DE PÓS-GRADUAÇÃO E PESQUISA EM PLANEJAMENTO URBANO E REGIONAL, 7., 22 maio 2017, São Paulo. Anais... São Paulo: Enanpur, 2017.

CAPELLO, R.; NIJKAMP, P. Handbook of regional growth and developmente theories. Northampton: Edward Elgar Publishing Limited, 2009.

COELHO, V. L. P. A PNDR e a nova fronteira do desenvolvimento regional brasileiro. Boletim Regional, Urbano e Ambiental, n. 17, p. 11-27, jul.-dez. 2017.

CRESCENZI, R.; GIUA, M. One or many cohesion policies of the European Union? On the differential economic impacts of Cohesion Policy across member states. Regional Studies, v. 54, n. 1, p.10-20, 2020.

DIJKSTRA, L.; POELMAN, H.; RODRÍGUEZ-POSE, A. The geography of EU discontent. Washington: CRPR, 2019. (CEPR Discussion Paper).

EC - EUROPEAN COMMISSION. EU budget: commission proposes a new fund to invest in the maritime economy and support fishing communities. 12 June 2018. Disponível em: $<$ https://bit.ly/3ov2Z4e>.

FALCK, O.; KOENEN, J.; LOHSE, T. Evaluating a place-based innovation policy: evidence from the innovative regional growth cores program in East Germany. Regional Science and Urban Economics, v. 79, n. 2, Nov. 2019.

FIASCHI, D.; LAVEZZI, A. M.; PARENTI, A. Does EU coesion policy work? Theory and evidence. Journal of Regional Science, v. 58, n. 2, p. 386-423, Mar. 2018.

IAMMARINO, S.; RODRIGUES-POSE, A.; STORPER, M. Regional inequality in Europe: evidence, theory and policy implications. Journal of Economic Geography, v. 19, n. 2, p. 273-298, Mar. 2019.

ISMAEL, R. Governos estaduais no ambiente federativo inaugurado pela Constituiçáo Federal de 1988: aspectos políticos institucionais de uma atuação constrangida. Rio de Janeiro: Ipea, 1990. (Texto para Discussão, n. 1907). 
LINHARES, P. T. F.; MENDES, C. C.; LASSANCE, A. Federalismo à brasileira: questóes para discussão. Brasília: Ipea, 2012. v. 8, 249 p.

MONTEIRO NETO, A.; PORCIONATO, G. L. As superintendências regionais de desenvolvimento: leis complementares de recriação e os planos regionais de desenvolvimento. Boletim Regional, Urbano e Ambiental, n. 17, p. 127-129, jul./dez. 2017.

MONTEIRO NETO, A. et al. Desenvolvimento regional no Brasil: realidade atual e perspectivas. Boletim Regional, Urbano e Ambiental, n. 15, p. 9-18, jul./dez. 2016.

- Desenvolvimento territorial no Brasil: reflexões sobre políticas e instrumentos no período recente e propostas de aperfeiçoamento. In: MONTEIRO NETO, A.; CASTRO, C. N.; BRANDĀO, C. A. (Org.). Desenvolvimento regional no Brasil: políticas, estratégias e perspectivas. Rio de Janeiro: Ipea, 2017a.

Avaliação qualitativa da Política Nacional de Desenvolvimento Regional (PNDR) e de seus instrumentos explícitos: uma percepção dos beneficiários e bancos operadores. In: RESENDE, G. M. (Ed.). Avaliaçáo de políticas públicas no Brasil: uma análise da Política Nacional de Desenvolvimento Regional (PNDR). Brasília: Ipea, 2017b. v. 3, 411 p.

PERCOCO, M. Impact of European cohesion policy on regional growth: does local economic structure matter? Regional Studies, v. 51, p. 833-843, 2016.

PÉREZ Y PÉREZ, L.; ÁNGEL, M.; CALVO, M. Regional cohesion in the EU: an analysis using the Lisbon index approach. Revista de Economía Mundial, n. 40, p. 169-196, 2015.

RESENDE, G. M. Avaliação de políticas públicas no Brasil: uma análise da Política Nacional de Desenvolvimento Regional (PNDR). Brasília: Ipea, 2017. v. 3, 411 p.

RESENDE, G. M.; MONTEIRO NETO, A. Avaliação continuada dos instrumentos da Política Nacional de Desenvolvimento Regional (PNDR). Boletim Regional, Urbano e Ambiental, n. 13, p. 65-66, jan./jun. 2016.

RESENDE, G. M.; SILVA, D. F. C.; SILVA FILHO, L. A. Avaliação dos efeitos econômicos dos fundos constitucionais de financiamento do Nordeste, do Norte e do Centro-Oeste: uma análise por tipologia da Política Nacional de Desenvolvimento Regional entre 1999 e 2011. In: RESENDE, G. M. (Ed.). Avaliação de políticas públicas no Brasil: uma análise da Política Nacional de Desenvolvimento Regional (PNDR). Brasília: Ipea, v. 3, 2017.411 p.

UE - UNIÃO EUROPEIA. Regulamento (CE) nº 1.080/2006 do Parlamento Europeu e do Conselho, de 5 de julho de 2006, relativo ao Fundo Europeu de Desenvolvimento Regional e que revoga o Regulamento (CE) $n^{\circ} 1.783 / 1999$. Jornal Oficial da Uniáo Europeia, $1^{\circ}$ ago. $2006 a$.

Regulamento (CE) no 1.081/2006 do Parlamento Europeu e do Conselho, de 5 de julho de 2006, relativo ao Fundo Social Europeu e que revoga o Regulamento (CE) n 1.784/1999. Jornal Oficial da União Europeia, 31 jul. 2006b. Disponível em: <https://bit.ly/3fsnISp >. 
Regulamento (CE) no 1.084/2006 do Conselho de 11 de julho de 2006, que institui o Fundo de Coesão e que revoga o Regulamento (CE) nº 1.164/94. Jornal Oficial da Uniáo Europeia, 31 jul. 2006c. Disponível em: <https://bit.ly/3eZS8fR>.

. A Política de Coesão da UE de 1988 a 2008: investir no futuro da Europa. Inforegio Panorama, n. 26, 2008.

Regulamento (CE) no 1.306/2013 do Parlamento Europeu e do Conselho, de 17 de dezembro de 2013, relativo ao financiamento, à gestão e ao acompanhamento da Política Agrícola Comum e que revoga os Regulamentos (CEE) no 352/78, (CE) no165/94, (CE) no 2.799/98, (CE) no 814/2000, (CE) nº 1.290/2005 e (CE) no 485/2008 do Conselho. Jornal Oficial da União Europeia, 20 dez. 2013. Disponível em: <https://bit.ly/3v7BT64>.

Regulamento (CE) no 508/2014 do Parlamento Europeu e do Conselho, de 15 de maio de 2014, relativo ao Fundo Europeu dos Assuntos Marítimos e das Pescas e que revoga

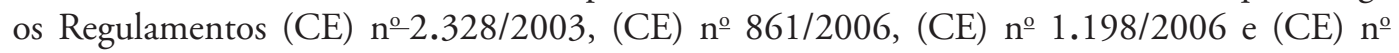
$791 / 2007$ do Conselho e o Regulamento (UE) no $1.255 / 2011$ do Parlamento Europeu e do Conselho. Jornal Oficial da Uniáo Europeia, 15 maio 2014. Disponível em: <https://bit. ly/3fsVHtL >. 
Ipea - Instituto de Pesquisa Econômica Aplicada

\section{EDITORIAL}

\section{Chefe do Editorial}

Reginaldo da Silva Domingos

\section{Assistentes da Chefia}

Rafael Augusto Ferreira Cardoso

Samuel Elias de Souza

\section{Supervisão}

Camilla de Miranda Mariath Gomes

Everson da Silva Moura

\section{Editoração}

Aeromilson Trajano de Mesquita

Anderson Silva Reis

Cristiano Ferreira de Araújo

Danilo Leite de Macedo Tavares

Jeovah Herculano Szervinsk Junior

Leonardo Hideki Higa

\section{Capa}

Danielle de Oliveira Ayres

Flaviane Dias de Sant'ana

\section{Projeto Gráfico}

Renato Rodrigues Bueno

The manuscripts in languages other than Portuguese published herein have not been proofread.

\section{Livraria Ipea}

SBS - Quadra 1 - Bloco J - Ed. BNDES, Térreo

70076-900 - Brasília - DF

Tel.: (61) 2026-5336

Correio eletrônico: livraria@ipea.gov.br 

Composto em adobe garamond pro 12/16 (texto) Frutiger 67 bold condensed (títulos, gráficos e tabelas) Brasilia-DF 



\section{Missão do Ipea}

Aprimorar as políticas públicas essenciais ao desenvolvimento brasileiro por meio da produção e disseminação de conhecimentos e da assessoria ao Estado nas suas decisões estratégicas.

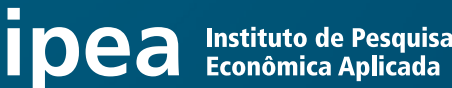 \\ MINISTÉRIO DA \\ ECONOMIA

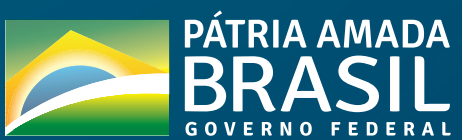

